\title{
A carbonate-banded iron formation transition in the Early Protorezoicum of South Africa
}

\author{
I. W. Halbich, D. LAmprecht, W. Altermann and U. E. Horstmann
}

Department of Geology, University of Stellenbosch, Stellenbosch 7600, Republic of South Africa

(First received 3rd June, 1992; revised form received 12th August, 1992)

\begin{abstract}
Seven new and two resurveyed stratigraphic sections through the important carbonate-BIF transition in Griqualand West are presented and compared with six published sections. Lateral correlation within this zone is attempted but the variability was found to be too great for meaningful subdivision. Substantial lithological irregularity is the only unifying character of this zone, for which the new name Finsch Member (Formation) is proposed. Vertical and lateral lithological variations as well as chemical changes across this zone are discussed with reference to environmental aspects. Local and regional considerations lead to the conclusion that fresh water-sea water mixing occurred in a shallowing basin.
\end{abstract}

\section{INTRODUCTION}

The apparently conformable Early Proterozolc transition from the Campbellrand carbonates to the Kuruman Iron Formation in the northern Cape Province is a boundary that deserves careful scrutiny.

Assuming that it is tectonically undisturbed all over (which is not certain at all, as will be shown below), the change in composition from carbonate to Fe-silicate is enough reason to carefully record the transition at as many sites as possible. Only a few cores are avallable. Man-made outcrops are confined to the Finsch open cast mine and the access road to the relay station at Gakarosa beacon (Fig. 1). Natural surface exposures with some topographic expression are numerous, but karsting in the underlying carbonates has commonly disturbed and recemented the beds in the iron formation. Shales, mudstones and black tuffites in iron formation, when pyrite-bearing, weather very rapidly and make extremely poor outcrops. However, compared to core sections, surface outcrops allow an accurate assessment of the superposition of bedding, the type of bedforms, as well as the larger types of internal bedding features. Thus slumping, contortions, tectonic folding, paleo-erosion features, local shear cleavage, brecciation, as well as dislocation parallel to and across bedding, are recognized with more confidence in surface and mine outcrops.

This contribution puts on record seven new transition profiles and two resurveyed ones. We try to correlate laterally the lithologies of 15 sections (Figs 1 and 11) over $450 \mathrm{~km}$ of strike. Changing environmental aspects thought to be recorded by the vertical transition and the lateral correlation are discussed.

\section{NEW PROFILES}

\section{Motivation}

In 1987, a very detailed ( $\mathrm{cm}$ scale) lithological and chemical survey of the transition zone in the Finsch open cast mine was conducted (Lamprecht. 1993). These revealed that $24 \mathrm{~m}$ of alternating cherts and ferruginous mudstones intervened between a lower $9 \mathrm{~m}$ thick sequence of BIF macrocycles and the upper continuous BIF sequence. Then. published sections of this transition (Beukes, 1978; 1980a; 1980b; 1983), some of which are still the best avallable and are therefore included in Fig. 11, did not record a prominent silici-clastic zone in the transition north of the Griquatown Fault (Fig. 1).

From 1988 to 1990, indisputable tectonic dupllcation was discovered in the Kuruman and Griquatown Iron Formations, south of the Griquatown Fault (Fig. 1) (Altermann and Hälbich, 1990). Bedding-parallel brecciation and intensely folded zones were discovered in new profiles measured north of the Griquatown Fault during 1988 and are reported on below. These findings cast some doubt on the stratigraphic correlations attempted previously from $\mathbf{N}$ to $\mathbf{S}$ across hundreds of kilometres of banded iron formations and based almost exclusively on borehole data (Beukes, op. cit). When Altermann and Herbig (1991) found shallow water limestone facies in the upper part of the Campbellrand Subgroup south of the Griquatown 
fault zone, where basinal facies had been assumed so far (e.g., Beukes, 1980a), it became clear that the environmental interpretations had to be re- considered for the two chemical sequences and their transition. More information on the comparatively narrow transition was therefore needed.

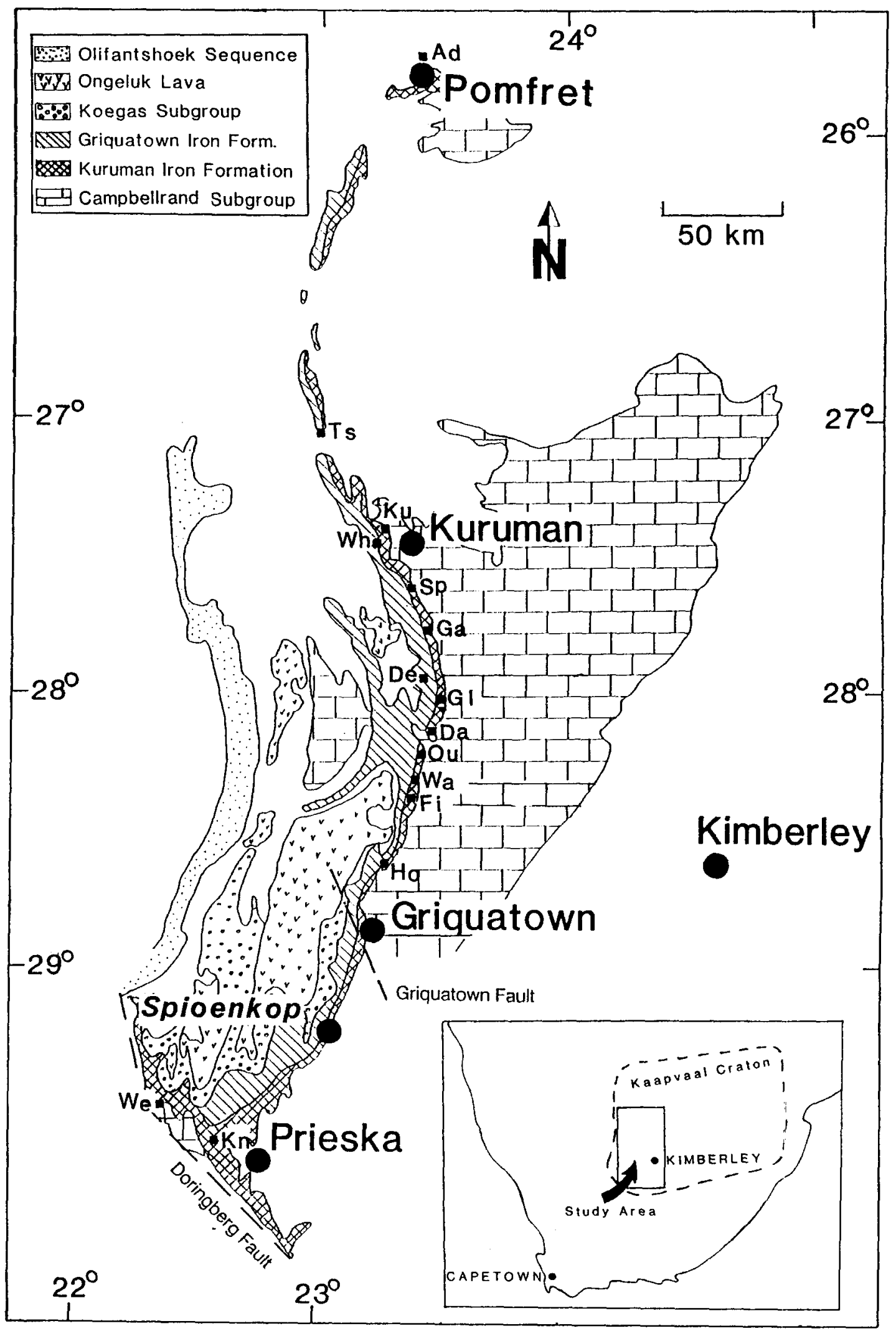

Fig. 1. Outcrop area of Asbesheuwels Subgroup (Kuruman and Griquatown Iron Formations) showing 15 section and profile sites of the transition zone (full squares). $\mathrm{AD}=$ Adelaide $\mathrm{BH} \mathrm{AD}-\mathrm{5}$ : Ts = Tsineng; $\mathrm{Ku}=\mathrm{Kurumankop}$; Wh $=$ White Bank, Bh Wb-98; Sp = Spitsberg; Ga = Gakarosa; De = Derby, BH DI-1; GL = Gladstone; Da = Danielskuil; Ou = Ouplaas; Wa = Warrendale; $\mathrm{FI}=$ Finsch Mine; Ho = Hopefield; $\mathrm{Kn}=$ Klein Naute; We = Westerberg; $\mathrm{BH}$ W-1. 


\section{The Finsch Profile}

Chemical analyses of the major and trace element contents of 50 selected samples covering all lithological changes observed in this profile (Fig. 2), reveal that in the iron formation i.e. units "e" and " $\mathrm{j}$ ", $\mathrm{K}, \mathrm{Na}, \mathrm{Ca}, \mathrm{Rb}$ and $\mathrm{Sr}$ have lower average concentrations as compared with core analyses from Griqualand West BIF and others world wide, (Horstmann and Häbich, submitted) whereas $A l$ is enriched. No detectable difference to the remaining major and trace elements has occurred. Twenty subsections were measured to $0.5 \mathrm{~cm}$ accuracy on eight benches (from $112 \mathrm{~m}$ to $208 \mathrm{~m}$ ) in Finsch Mine (Fig. 2a). Correlation from one subsection to the next was controlled using sets of marker mesobands. Care was taken to stay away from karsted and slumped areas and from several thin kimberlite dykes. Dips to the west are extremely low, measurable by extrapolation only. The lithological description in Fig. $2 b$ is used in the following discussion.

What follows is a resumé of conclusions drawn from a detalled environmental analysis by D. F. Lamprecht (1993).

Unit "a" has beds of microscopic pellets and sedimentary breccias. These and cryptalgal mats, with conophyton-like structures only a few $\mathrm{mm}$ high, point to shallow water and periodically higher kinetic energy, in spite of the upward increasing frequency of black, pyritic shales. It is concluded that this unit was deposited in mainly tranquil waters, with anoxic conditions underneath the sediment/water interface, producing black shales that were periodically stirred up. A sheltered bay or lagoon behind a barrier island or carbonate reef is envisaged. Conditions were mainly marine, the $\mathrm{pH}$ being $>7$ but $<9$. Cyclicity was probably seasonally controlled. Rtver influx was low and biogenic activity at the sediment-water interface high, with slow burial rates.

Carbonate precipitation is enhanced and cyclicity drastically reduced in unit " $\mathrm{b}$ ". Better sheltering and even lesser clastic influx, if any, are indicated.

The first occurrence of regular, microbanded cherty layers in unit " $c$ " is accompanied by decreasing blogenic remains (Fig. 2b, graphs). Thus, conditions either became too harsh for living forms or their remains were oxidized before burial because of too low burial rates. Clastic input was virtually absent and $\mathrm{pH}$ dropped below 7 , to allow chert to precipitate. A stronger, at least periodic but very sluggish fresh water inflow or excessive periodic rain into a practically closed environment is indicated. The cyclicity is pronounced and was probably seasonally (evaporation) controlled. Fe$\mathrm{Mg}$ precipitation is registered in ankerite-siderite mineralization.

This trend is continued with a massive ankeritic chert in unit " $d$ ". Throughout units " $c$ " and " $d$ " the $\mathrm{Fe} / \mathrm{Mg}$ ratio steadily increases upwards (Fig. $2 \mathrm{~b}$. graphs). As from unit "e" upwards, $\mathrm{SiO}_{2}$ and $\mathrm{Fe}_{2} \mathrm{O}_{3}$ are the dominant major oxides together making up some $88 \%$ of banded ironstone (units "e" and "j") and $84 \%$ of mudstones (units " $f$ " to "i") in Fig. 2b (Table 1). This means that a very sudden and drastic change occurred in the source supplying solute to the water body as well as in redox and $\mathrm{pH}$ conditions. At the same stratigraphic level the preservation of stilpnomelane mesobands of volcaniclastic origin is recorded in the profile (La Berge, $1966 a+b)$. The distribution of these tuffites

Table 1. Density and length weighted averages of major element oxides in the transition zone.

\begin{tabular}{|lccccccc|}
\hline $\mathrm{Unit}^{*}$ & $\mathrm{j}$ & $\mathrm{h}+\mathrm{i}$ & $\mathrm{g}$ & $\mathrm{f}$ & $\mathrm{e}$ & $\mathrm{e}+\mathrm{j} / 2$ & Aver. $\mathrm{f}$ to $\mathrm{j}$ \\
\hline $\mathrm{SiO}_{2}$ & 46.04 & 61.67 & 64.54 & 18.01 & 57.57 & 50.02 & 46.46 \\
\hline $\mathrm{TiO}_{2}$ & 0.06 & 0.12 & 0.6 & 0.07 & $\mathrm{nd}$ & 0.04 & 0.17 \\
\hline $\mathrm{Al}_{2} \mathrm{O}_{3}$ & 1.31 & 2.41 & 12.89 & 1.62 & 0.26 & 0.93 & 3.56 \\
\hline $\mathrm{Fe}_{2} \mathrm{O}_{3}$ & 38.71 & 27.9 & 7.93 & 64.06 & 36.8 & 38.02 & 38.12 \\
\hline $\mathrm{MnO}$ & 0.19 & 0.36 & 0.04 & 2.36 & 0.03 & 0.15 & 1.03 \\
\hline $\mathrm{MgO}$ & 2.15 & 0.7 & 1.43 & 0.91 & 0.71 & 1.63 & 0.87 \\
\hline $\mathrm{CaO}$ & 2.61 & 0.99 & 0.46 & 1.18 & 1.67 & 1.98 & 0.98 \\
\hline $\mathrm{Na}_{2} \mathrm{O}$ & 0.21 & 0.08 & 0.12 & 0.1 & 0.09 & 0.11 & 0.1 \\
\hline $\mathrm{K}_{2} \mathrm{O}$ & 0.08 & 0.08 & 5.92 & 0.24 & nd & 0.05 & 0.94 \\
\hline $\mathrm{P}_{2} \mathrm{O}_{5}$ & 0.08 & 0.07 & 0.05 & 0.68 & 0.07 & 0.07 & 0.29 \\
\hline $\mathrm{LOI}$ & 7.53 & 4.4 & 3.9 & 8.39 & 2.87 & 5.85 & 5.76 \\
\hline $\mathrm{H}_{2} \mathrm{O}$ & 1.84 & 2.57 & 1.4 & 1.77 & 0.46 & 1.34 & 2.12 \\
\hline Tot. & 100.81 & 101.35 & 99.28 & 99.39 & 100.53 & 100.37 & 100.4 \\
\hline
\end{tabular}

* See stratigraphic units in Fig. 2b. 

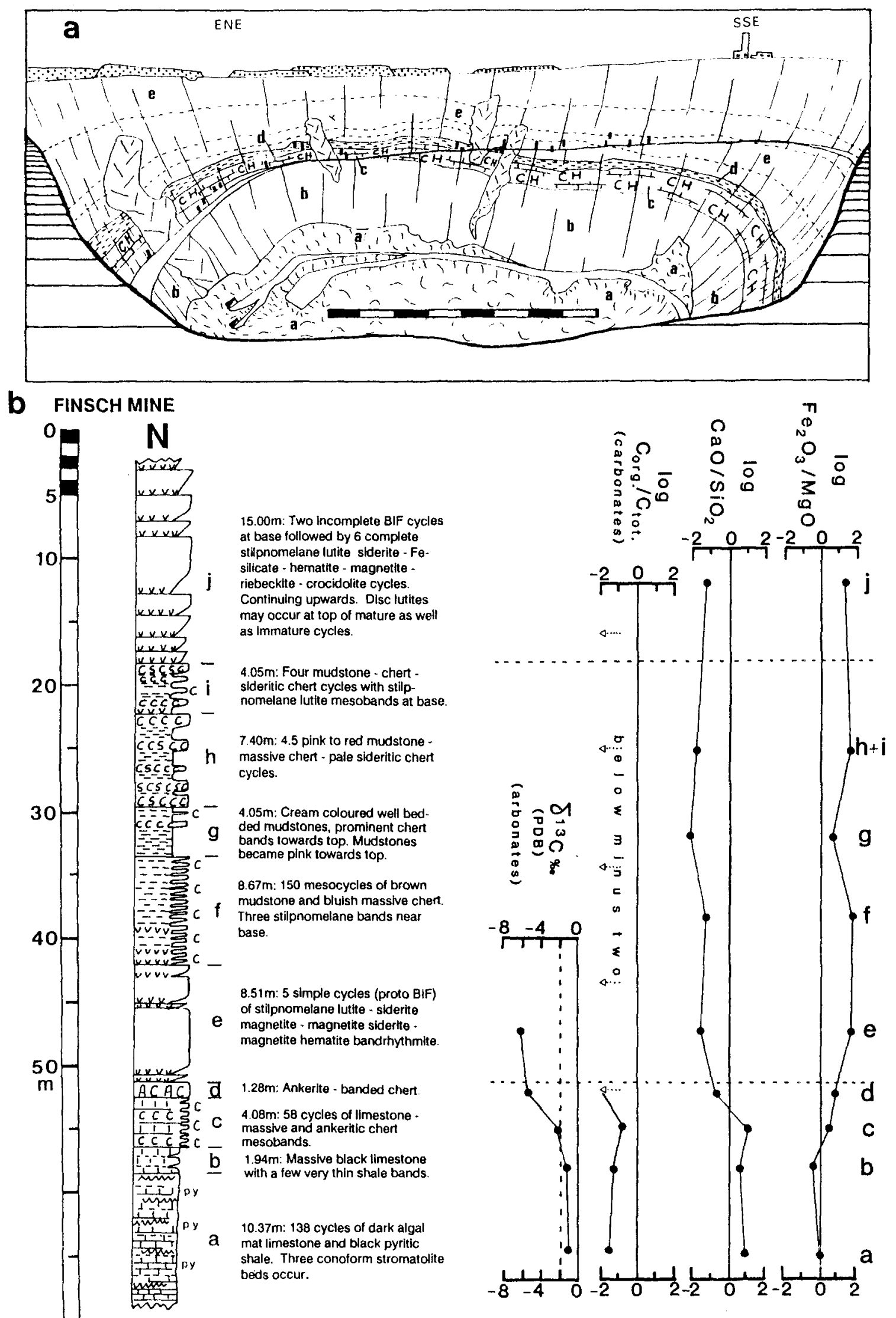

Fig. 2 a. Finsch Open Pit. About $1 \mathrm{~km}$ in diameter and $350 \mathrm{~m}$ deep, looking ESE from rim of pit. Bar scale $=400 \mathrm{~m}$. Access road descends from right to left. $a=$ Kimberlite. $b=$ carbonates of Campbellrand (units " $a$ " and " $b$ " of Fig. $2 b$ ) $c=$ lower cherty horizons and proto BIF (Units c, $d$ and $e$ of Fig. 2b. $d=$ Mudstones and cherty mudstones (units $f, g, h$ and $i$ of Fig. $2 b$ ) $e=B I F$ of Kuruman I. F. (units $\mathrm{j}$ of Fig. $2 \mathrm{~b}$. Oblique signature = karsted areas. Dumps on horizon. Short black vertical bars $=$ sampled subsections above access road level. $\quad$ (b) Stratigraphic section. Detall of transition zone with important chemical parameters. 
has an important bearing on their origin, their chances for preservation and therefore the type of environment in which they were deposited. In units "a" to "d", consisting of predominantly chemical and/or biochemical sediments, no ash layers are recorded, whereas in units " $\mathrm{f}$ " and " $\mathrm{l}$ " ash layers are pre-served mainly in clastic sediments This means that the presence or absence of these tuffites in the transition zone was directly related to the availability of ash in the atmosphere at that time, and was not a function of water tranquillity or preservation. However, when other clastic material was also introduced to the environment (units " $\mathrm{f}$ " and " $\mathrm{f}$ ") volcanic ash was no longer part of the usual Fe-carbonate-silicate-oxide cycles of typical BIF precipitation as for units "e" and " $\mathrm{j"}$ (Beukes, 1978, p. 402-411).

Where $\mathrm{Al}_{2} \mathrm{O}_{3}$ values are high (13\%), as in the chert-poor unit " $g$ ", the Fe-content reaches maximum concentrations (64 \%) in the Kuruman Iron Formation (Table 1). The density and volume (length) weighted average composition of the mudstone units "f", "g", " $h$ " and " $i$ " is very close to that of the average BIF in this section (Table 1). The most significant differences are those in $\mathrm{Al}_{2} \mathrm{O}_{3}(3.56 \%$ for mudstone vs. $0.93 \%$ for $\mathrm{BIF})$ and $\mathrm{K}_{2} \mathrm{O}(0.94 \%$ for mudstone vs. $0.05 \%$ for BIF) which clearly confirms that during mudstone precipitation a fine clay mineral-enriched clastic fraction was added to an environment that was essentially conductve to chemical/biochemical BIF-precipitation.

The temporary influx of clastic material seems to have disturbed the full rhythmic cycle of BIF deposition that had started in unit "e", reducing it to a ferruginous mudstone-chert rhythm. The cherts are almost pure $\mathrm{SiO}_{2}$. Nevertheless, volcanic ash was laid down as separate units whenever it became avallable. Unit "j" was deposited when clastic influx almost ceased la small contribution is still indicated by $\mathrm{Al}_{2} \mathrm{O}_{3}=1.3 \%$ for unit "j" as compared to $0.26 \%$ for unit "e", Table 1), and full BIF cycles started to form, each time interrupted by a tuff layer as described by Beukes $(1978 ; 1980 \mathrm{~b})$.

$A \delta^{13} \mathrm{C}$ vs stratigraphy plot of carbonate carbon in units "a" to "e" as conducted by Lamprecht (1993), reveals that where organic carbon is no longer preserved as in unit "c", mineral carbon becomes $\delta{ }^{13} \mathrm{C}$-deficient, indicating that even under the oxygen-poor $(<0.01 \mathrm{x}$ atmospheric) conditions of the Early Proterozoic, most organic material disintegrated when bural was very slow, water depth was extremely shallow and the basin became restricted. A comparison with fresh as against marine water carbonates classified according to a $\delta^{13} \mathrm{C} / \delta^{18} \mathrm{O}$ plot (Keith and Weber, 1964) shows that unit "c" marks the transition from "marine to fresh water" with $\delta^{13} \mathrm{C}>-2 \%$, and increasing stratigraphically upwards into unit "e" (Fig. 2b, graphs). $\delta{ }^{13} \mathrm{C}$ exceeding -4 as in units " $\mathrm{d}$ " and "e" are indicattve of fresh water carbonates according to Hoefs (1987).

Shallow and comparattvely well-aerated sea water with fresh water admixture is also indicated for units "a" and "d" by $\delta{ }^{34} \mathrm{~S}$ of matrix pyrite -0.0 in shale and carbonate samples. Fe and sulfate depletion in a rapidly buried sediment interface likewise point to fresh water admixture for all units below "e". A $\delta{ }^{34} \mathrm{~S}$ at -13.9 for early diagenetic nodules (suffering from compaction) in the shales of units "a" and "b" means that the bulk of the system was closed rather rapidly, during sedimentation, but individual colonies of reducing bacteria were able to thrive locally during diagenesis.

A $\delta{ }^{13} \mathrm{C}$ (organic) around -40 in the abovementioned units is of the lowest so far reported for the Proterozoic (see also Beukes et al., 1990). This is typical of the late Archean when methanogenic processes, fermentation and sulfate reduction (Baur et al., 1985) caused $\delta{ }^{13} \mathrm{C}$ depletion at the sediment-water interface. These processes may have been coupled to the origin of life in very shallow, transitional waters from which photosynthetic and eukaryotic algae were absent (Hoefs, 1987: Schidlowskl et al. 1983).

A very low but steadily increasing sodium concentration in carbonates from "a" to "d" Indicates a gradual change from marine to brackish or mixed water conditions (Wedepohl, 1970).

Throughout this profile we see that there is no need for a gradually deepening water body to explain the carbonate-BIF transition. Arguments based on the Iron-silica source are beyond the scope of the present treatment.

From the mudstone-interrupted BIF precipitation recorded in this profile, it seems that:

(a) The Kuruman I. F. should be seen to start at the base of the first BIF-cycle because it marks the most profound change in water chemistry reflected in the lithology.

(b) Shallow fresh water-contaminated conditions cannot be disregarded as an environment in which these BIFs were deposited, whatever the origin of $\mathrm{Fe}$ and Si.

(c) A very rapid carbonate to carbonate-silica to Fe-oxide-silica transition occurred interrupted initially by fine clastic contributions.

(d) Full BIF cycles only form in water almost free of a clastic load.

(e) A distal volcanic ash input disrupts the normal oxide-silicate cycle leading to a more complex cyclicity.

(f) Tuff contributions are not a direct cause for BIF-precipitation but an indirect link seems to exist in that the atmospheric conditions and the weathering cycle are affected, leading to higher $\mathrm{Fe}$ - 


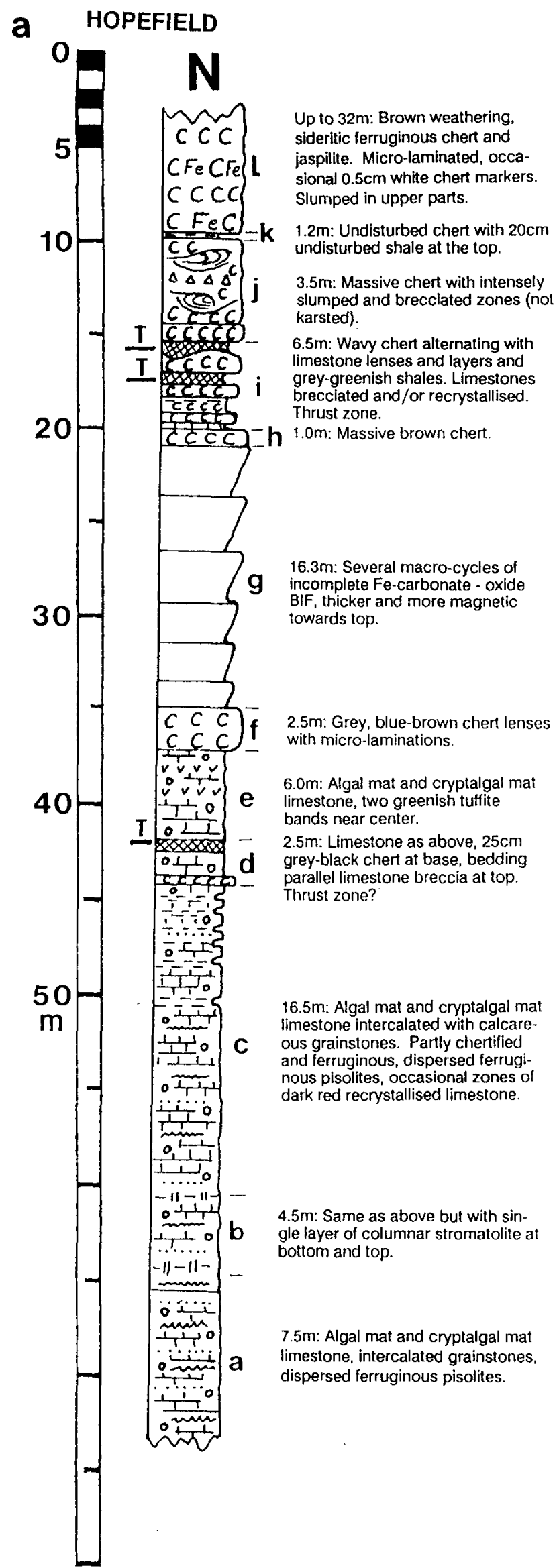

and $\mathrm{Si}$-concentrations and lower Ca-concentrations in the water body.

The next 8 profles will be compared individually with the Finsch section to ascertain the degree of correlation and briefly discuss possible environmental implications.

\section{Hopefield Profile}

This profile (Fig. 3), $28 \mathrm{~km}$ south of Finsch Mine, is only partly preserved because of erosion at the top, and it seems to be disturbed, probably by thrusting in at least 3 or 4 localities where recrystallized limestones or brecciated chert and BIF are encountered. Repetition by thrusting is possible but cannot be proved beyond doubt.

Nevertheless, a resemblance to the Finsch section is seen in the separation of a lower BIF sequence from an upper altered (jaspilised) ferruginous chert unit which elsewhere in this area is overlain by typical Kuruman I.F. A chert-shale sequence (shortened tectonically?) intervenes. The carbonates of units "b" to "e" compare well with those at Finsch but the cherty zone is different, possibly because of tectonic disturbance. Possible tuffaceous layers in carbonates are a new element. There is no reason to doubt the onset of typical BIF precipitation with unit $g$. Therefore this forms the base of the Kuruman I. F. The lower BIF sequence possibly correlates with that at Finsch.

\section{The Klein Naute profile}

Located some $115 \mathrm{~km}$ south of Hopefield and beyond the Griquatown Fault zone, this section (Fig. 4) has $58 \mathrm{~m}$ of grey, cleaved shales of unit "a* before hematitic chert-tuffite-shale units " $b$ " to "d" intercept the monotony. These are succeeded by
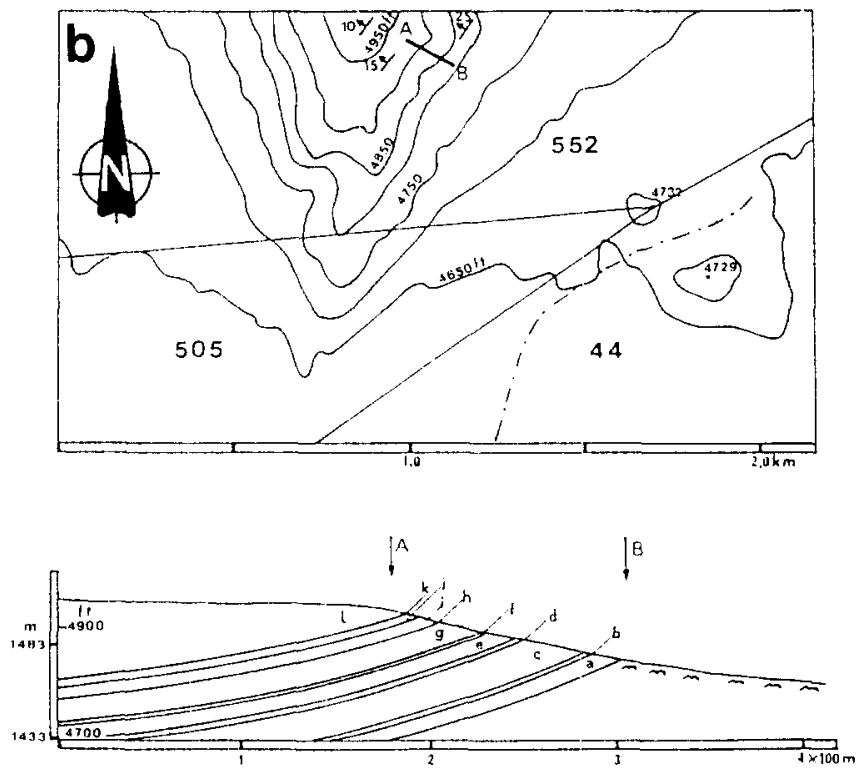

Fig. 3a. Hopefield. On Hopefield Estate 552 (Fig. 1) this profile was accurately measured by means of a Jacob staff some $2 \mathrm{~km}$ south east of the old Hopefield Mine. Dips vary from $25^{\circ}$ to $15^{\circ}$. Dot-dash line is access farm road. Straight full lines are farm boundaries. (b) Hopefield. Stratigraphic section: detail of transition zone. 


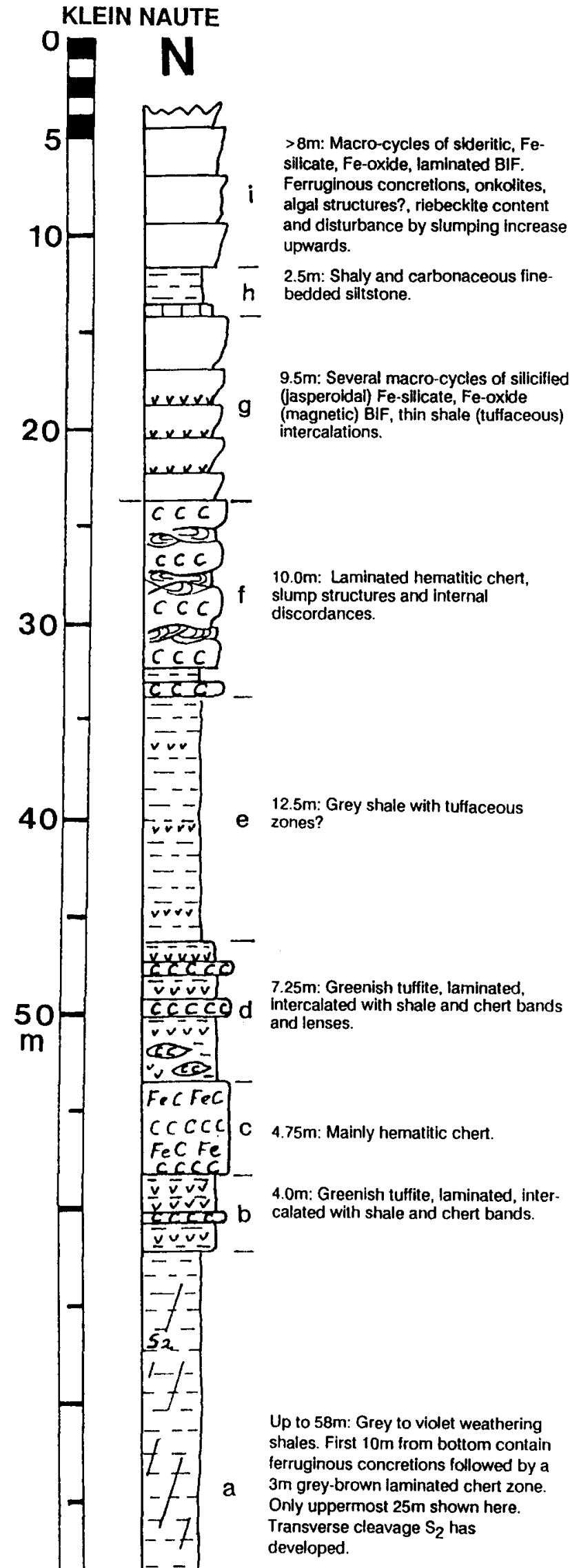

some more shales and tuffites until intensely slumped iron-rich cherts of unit "f" are overlain by genuine-cyclic BIF only once more interrupted by a thin shale in " $h$ ". The sequence " $b$ " to " $f$ " has a thickness of about $37 \mathrm{~m}$, very closely comparable to that of the Finsch profile between the first cherts and the second BIF unit. Another common feature is the frequent tuffite layers. Both this and the Finsch profile bear no obvious signs of disturbance by faulting (Fig. 11).

Although a lithological similarity does exist there is also the great thickness of shales: below " $b$ " pointing to environmental differences. More fine clastic material and an environment initially not quite as conducive to regular BIF precipitation as that north of the Griquatown Fault because of a higher fresh water influx, are indicated. This agrees with an earlier intertidal to supratidal carbonate environment (Altermann and Herbig, 1991). Tuffs again mark the onset of ferruginous chert precipitation when clastic influx is not too high, and an indirect link with a Fe-silicate-cycle is suggested. Altermann (1991) reported that tuffs in carbonates below the Naute Shale became more prominent and more proximal towards the south in the Prieska-Koegas area (Fig. 1). The thickness of the Naute Formation also increases southwards. A closer proximity of this part of the basin to gently uplifted areas (possibly in the south and west) than for the area north of the Griquatown Fault is indicated. The base of the Kuruman Iron Formation could possibly be at the base of " $b$ " but conveniently is located at the base of " $\mathrm{g}$ " in Fig. 4.

\section{The Warrendale profile}

Here, only a few kilometres north of Finsch Mine, the stratigraphic section is very incomplete because of slumping and brecciation of BIF during karst formation (Fig. 5). Only one undisturbed non-ferruginous chert (unit g) is preserved at the base of the BIF sequence. Below that the limestones of unit " $\mathrm{f}$ " contain elements of a shallow subtidal to intertidal environment (small domal stromatolites) but also grainstones indicative of active erosion of algal mats. Conspicuous are the regular ferruginous shale intercalations representing pyritic muds. As discussed under the Finsch profile, anoxic conditions prevailed in the Early Proterozoic, which was possible because of an oxygen-poor atmosphere. The uppermost $4 \mathrm{~m}$ of iron-free black chert intercalations are reminiscent of unit "b" at Finsch. The base of the Kuruman Iron Formation can only be estimated to occur just above unit " $\mathrm{g}$ ".

Fig. 4. Kein Naute. Accurately taped very steep section on farm Klein Naute (Fig. 1) at the Orange River. Covers the entire transition zone from the Campbellrand carbonates into the Kuruman I. F. Dips are very low, $10^{\circ}$. 
a

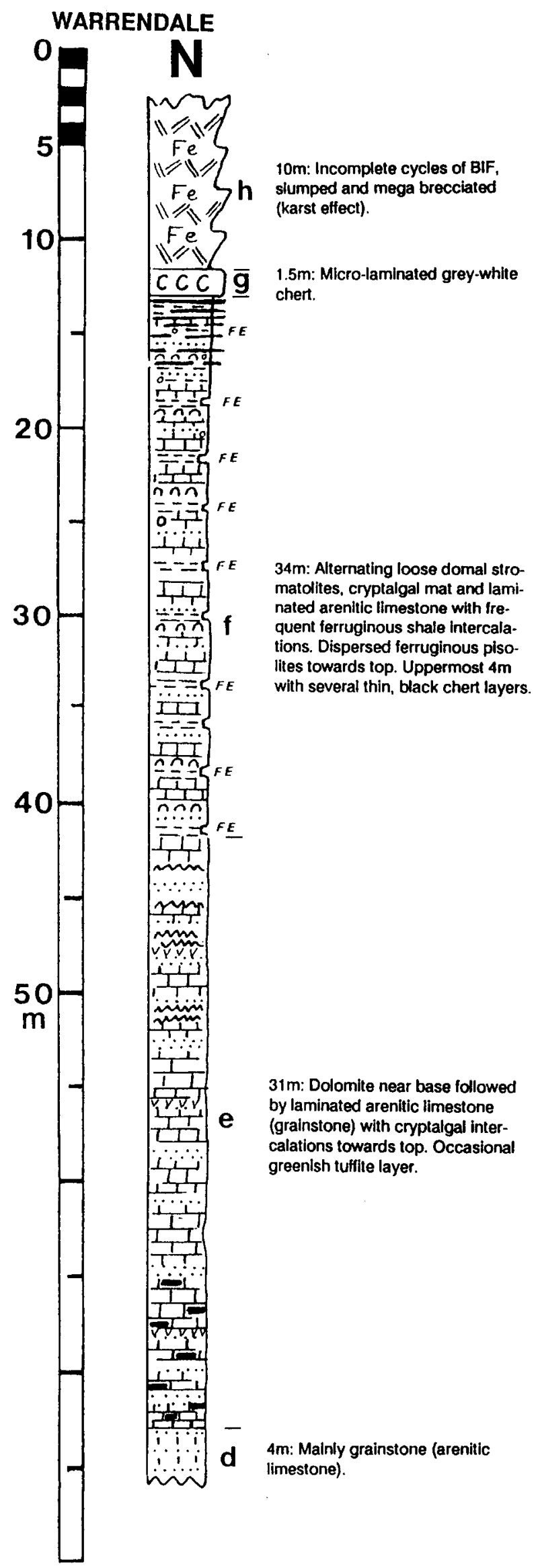

b
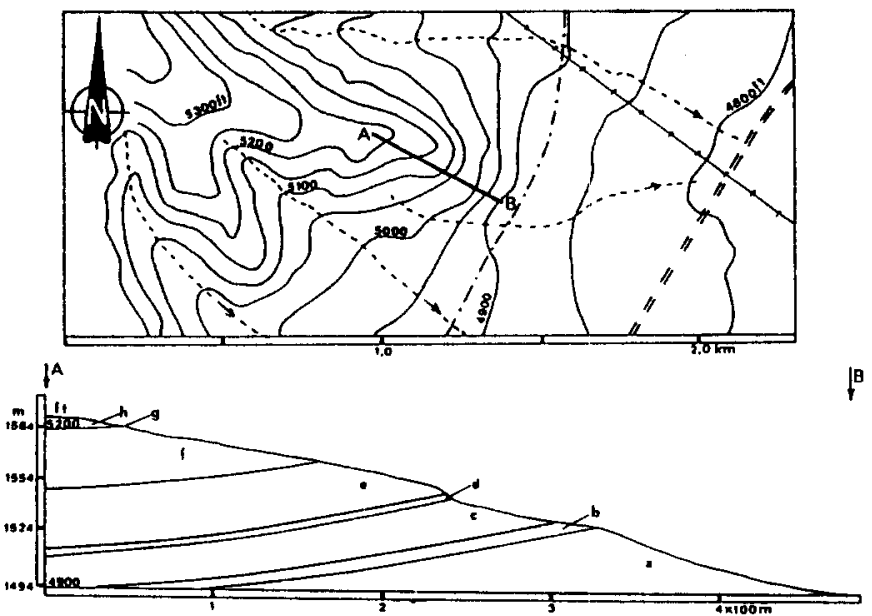

FYg. 5a. Warrendale. On the farm Warrendale $(5 \mathrm{~km}$ north of Lime Acres, Finsch Mine) (Fig. 1). Section locality (top) and profle (bottom). A topographic profile and measured dips were used to estimate the thickness. Unit a: Stromatolitic limestones and carbonaceous grainstones. Unit b: About $7 \mathrm{~m}$ of mainly arenitic limestone. Unit c: $26 \mathrm{~m}$ of cryptalgal mat limestone with occasional layer of domal stromatolite towards top. Rest of column see b). Dashed lines are drainage lines. Dash-dot $=$ old road. Double dash $=$ main road. Full line with barbs $=$ power line. Fig. 5b. Warrendale. Stratigraphic section: detail of transition zone.

\section{The Gladstone section}

This section, located $26 \mathrm{~km}$ north of Finsch Mine and just $8 \mathrm{~km}$ north of Danielskuil, has also been subject to karsting at the top (Fig. 6). However, it is clear from the undisturbed part that considerable similarity to the lower parts of the Finsch and Hopefleld sections exists. A lower sequence of BIF macrocycles overlies cryptalgal mat limestones with originally pyritic nodules and very thin shales at the top (unit "e") whereas a clean, thick chert unit is again present (unit "d"). The shales of unit " $\mathrm{g}$ " and the cherts of unit " $\mathrm{h}$ " could represent an inversion of " $\mathrm{d}$ " and " $\mathrm{e}$ ". They are also reminiscent of what happens in "g" and " $h$ " at Finsch Mine and " $\mathrm{i}$ " and " $\mathrm{j}$ " at Hopefield. It is clear that the first attempt at regular BIF precipitation in the environment was interrupted by clastic influx everywhere, but north of the Griquatown Fault zone this influence was subdued allowing full BIF to continue being deposited for a few cycles whereas south of the fault full cycles could not develop early on because of a greater influx of mud. Consequently the transition north of the fault was more gradual. The base of the Kuruman Iron Formation would be at the base of unit " $\mathrm{f}$ ".

\section{The Gakarosa section}

Some $29 \mathrm{~km}$ further north at Gakarosa a full profile (Fig. 7) very similar to that at Finsch was discovered. Even the thicknesses of BIF and intervening shale/mudstone units are closely comparable. Mainly algal mat carbonates with pyritic nodules, shale and chert intercalations 


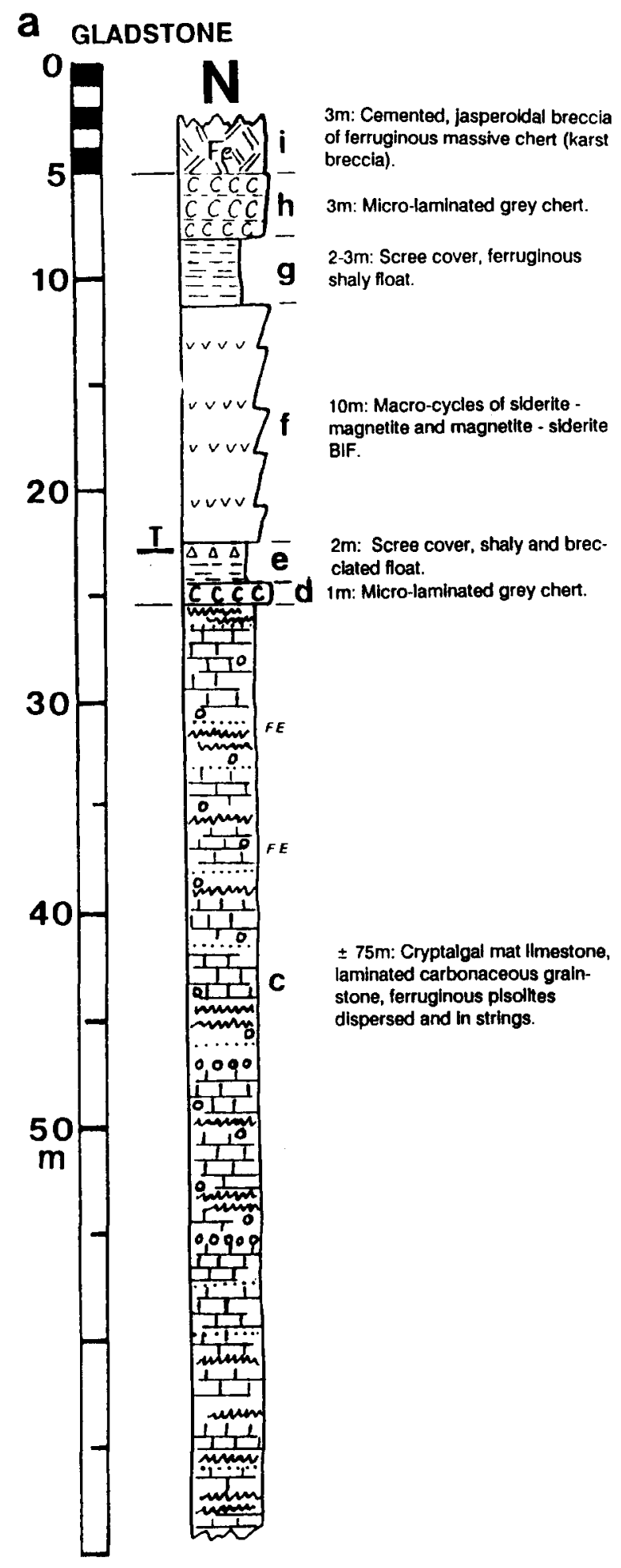

Fig. 6a. Gladstone. Just west of the Gladstone farmhouse (Fig. 1). Section locality (top) and profile (bottom). Thicknesses are estimated, dip corrected and fitted to the topographic profile A-B. Dips change more than usual. Unit a: Featureless grey, laminated limestones. Unit b: Some $140 \mathrm{~m}$ of stromatolitic (columnar and domal) limestone with a cauliflower marker $5=b_{1}$. Rest of column see b). Dashed line = drainage. Double dash $=$ main road.

Fig. 6b. Gladstone. Stratigraphic section: detail of transition.

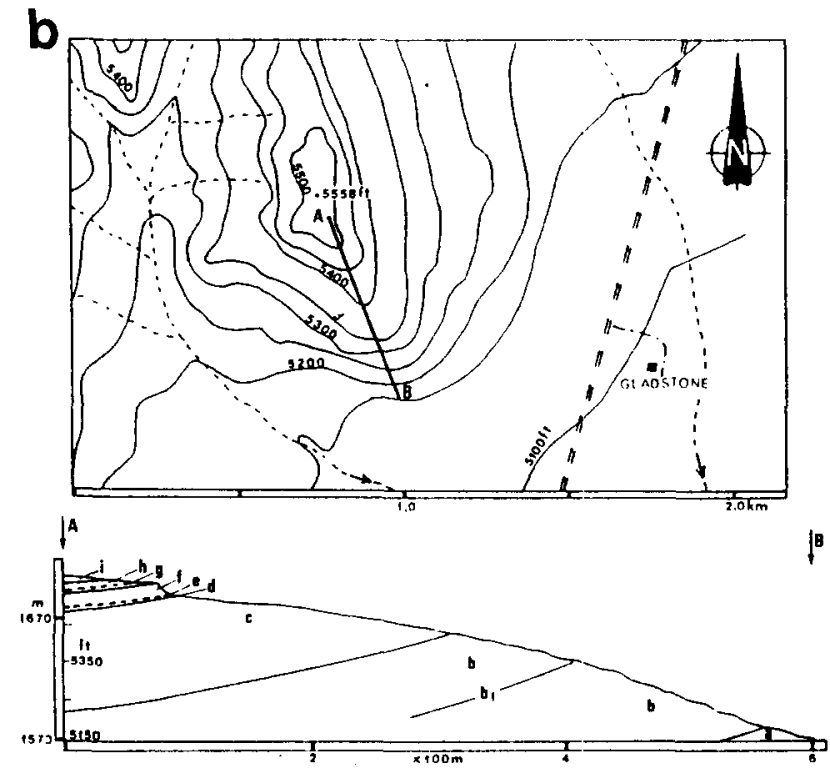

towards the top are terminated by a thick, pure chert band (unit e). The first sequence of BIF macrocycles is followed by a shale-chert sequence " $h$ "and a chert-shale alternation " $i$ " on which continuous BIF cycles are deposited. Tuffite layers are not present in this profile. The disturbed nature of the shales and chert layers in unit " $h$ " may point to some duplication by thrusting. The Kuruman Iron Formation in this profile starts at the base of " $f$ ".

\section{The Spitsberg proflle}

Three attempts at full BIF precipitation are recorded here (Fig. 8) some $35 \mathrm{~km}$ north of Gakarosa. From the first continuous chert deposition in ferruginous pisolitic limestone (unit c) to the final onset of continuous BIF-cycles (unit " $h "$ ) again some $36-37 \mathrm{~m}$ of transitional facies occur. closely comparable to Gakarosa, Finsch and Hopefield. This thickness is even comparable to that between units " $\mathrm{b}$ " and " $\mathrm{g}$ " at Klein Naute. Except for some thrusting indicated at the top of unit "e", which may be responsible for the threefold BIF repetition, and less regular chert and shale intercalations, environmental conditions seem to have been very similar to those at Finsch. In this case the base of the Kuruman Iron Formation is not readily determined by using the criterion employed so far.

\section{The White Bank Section}

Another $25 \mathrm{~km}$ farther north the White Bank core as surveyed by us (R, (Fig. 9) has $30 \mathrm{~m}$ of chertshale-carbonate transition (units " $P$ ' to " $k$ "). No full BIF-cycles have developed below unit " $k$ ", in which some tectonic duplication occurs at least on a very local scale. Thicker shale intercalations are found lower down in unit "d". (Compare the sections from Danielskuil, Ouplaas, Tsineng and Kurumankop: 

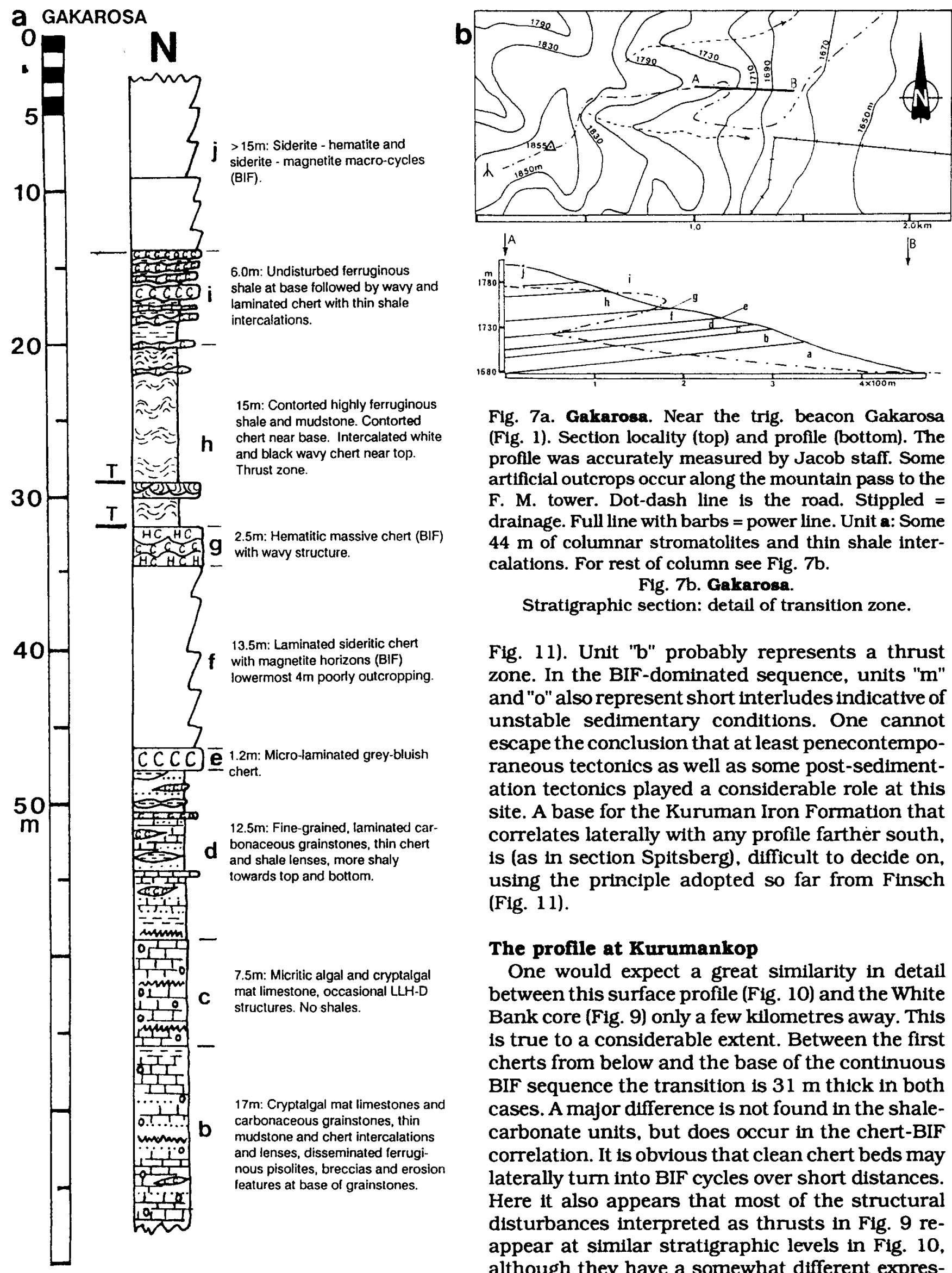

Fig. 7a. Gakarosa. Near the trig. beacon Gakarosa (Fig. 1). Section locality (top) and profile (bottom). The profile was accurately measured by Jacob staff. Some artificial outcrops occur along the mountain pass to the F. $M$. tower. Dot-dash line is the road. Stippled = drainage. Full line with barbs = power line. Unit a: Some $44 \mathrm{~m}$ of columnar stromatolites and thin shale intercalations. For rest of column see Fig. $7 \mathrm{~b}$.

Fig. 7b. Gakarosa.

Stratigraphic section: detail of transition zone.

Fig. 11). Unit " $b$ " probably represents a thrust zone. In the BIF-dominated sequence, units " $m$ " and "o" also represent short interludes indicative of unstable sedimentary conditions. One cannot escape the conclusion that at least penecontemporaneous tectonics as well as some post-sedimentation tectonics played a considerable role at this site. A base for the Kuruman Iron Formation that correlates laterally with any profile farther south, is (as in section Spitsberg), difficult to decide on, using the principle adopted so far from Finsch (Fig. 11).

\section{The profile at Kurumankop}

One would expect a great similarity in detail between this surface profile (Fig. 10) and the White Bank core (Fig. 9) only a few kilometres away. This is true to a considerable extent. Between the first cherts from below and the base of the continuous BIF sequence the transition is $31 \mathrm{~m}$ thick in both cases. A major difference is not found in the shalecarbonate units, but does occur in the chert-BIF correlation. It is obvious that clean chert beds may laterally turn into BIF cycles over short distances. Here it also appears that most of the structural disturbances interpreted as thrusts in Fig. 9 reappear at similar stratigraphic levels in Fig. 10, although they have a somewhat different expression. The two sections also have in common shalecarbonate-chert cycles which developed in the 

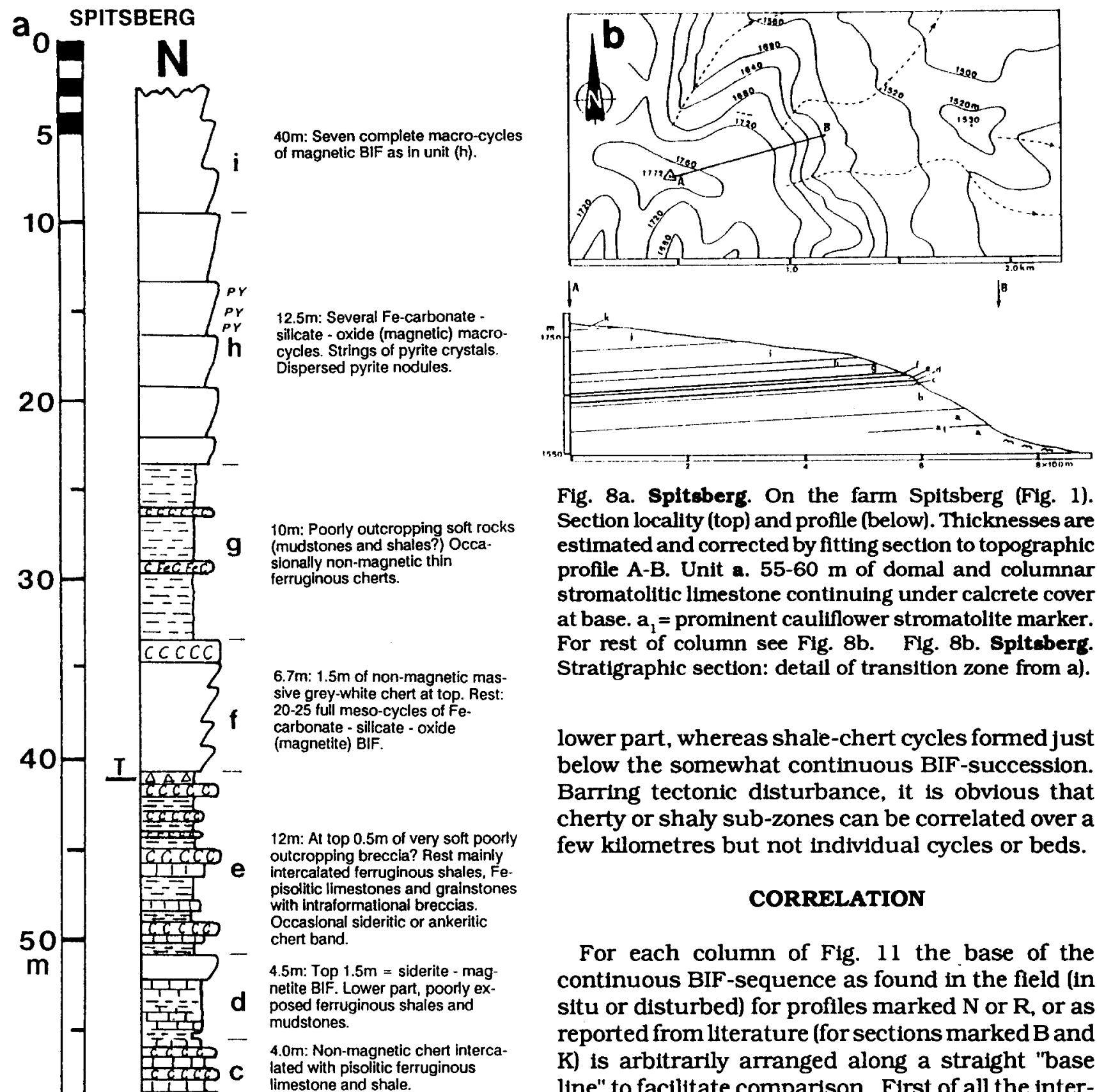

Fig. 8a. Spitsberg. On the farm Spitsberg (Fig. 1). Section locality (top) and profile (below). Thicknesses are estimated and corrected by fitting section to topographic profile A-B. Unit a. 55-60 $\mathrm{m}$ of domal and columnar stromatolitic limestone continuing under calcrete cover at base. $a_{1}=$ prominent cauliflower stromatolite marker. For rest of column see Fig. $\mathbf{8 b}$. Fig. 8 b. Spitsberg. Stratigraphic section: detail of transition zone from a).

lower part, whereas shale-chert cycles formed just below the somewhat continuous BIF-succession. Barring tectonic disturbance, it is obvious that cherty or shaly sub-zones can be correlated over a few kilometres but not individual cycles or beds.

\section{CORRELATION}

For each column of Fig. 11 the base of the continuous BIF-sequence as found in the field (in situ or disturbed) for profiles marked $\mathrm{N}$ or $\mathrm{R}$, or as reported from literature (for sections marked $B$ and $\mathrm{K})$ is arbitrarily arranged along a straight "base line" to facilitate comparison. First of all the interauthor error must be determined. Comparing the Orange View-Klein Naute profiles, it is clear that very similar sequences were recorded, but there are some notable differences which may or may not be real, because the exact distance between these profiles on Klein Naute farm is unknown. Our "b" to "d" section obviously coincides with Beukes' zone 3 of Beukes (1980b), but we record tuff and a reduced length. Some individual chert-rich units cannot be identified in both sections. We also record a transverse cleavage $S_{2}$ in the lower shale sequence.

As for the Hopefield profiles again the coincidence of position is uncertain. We suggest a lateral correlation of $\mathrm{B}$ with $\mathrm{N}$ as shown on Fig. 11, mainly relying on chert bands and shaly horizons. From this it seems that section $B$ is even less 


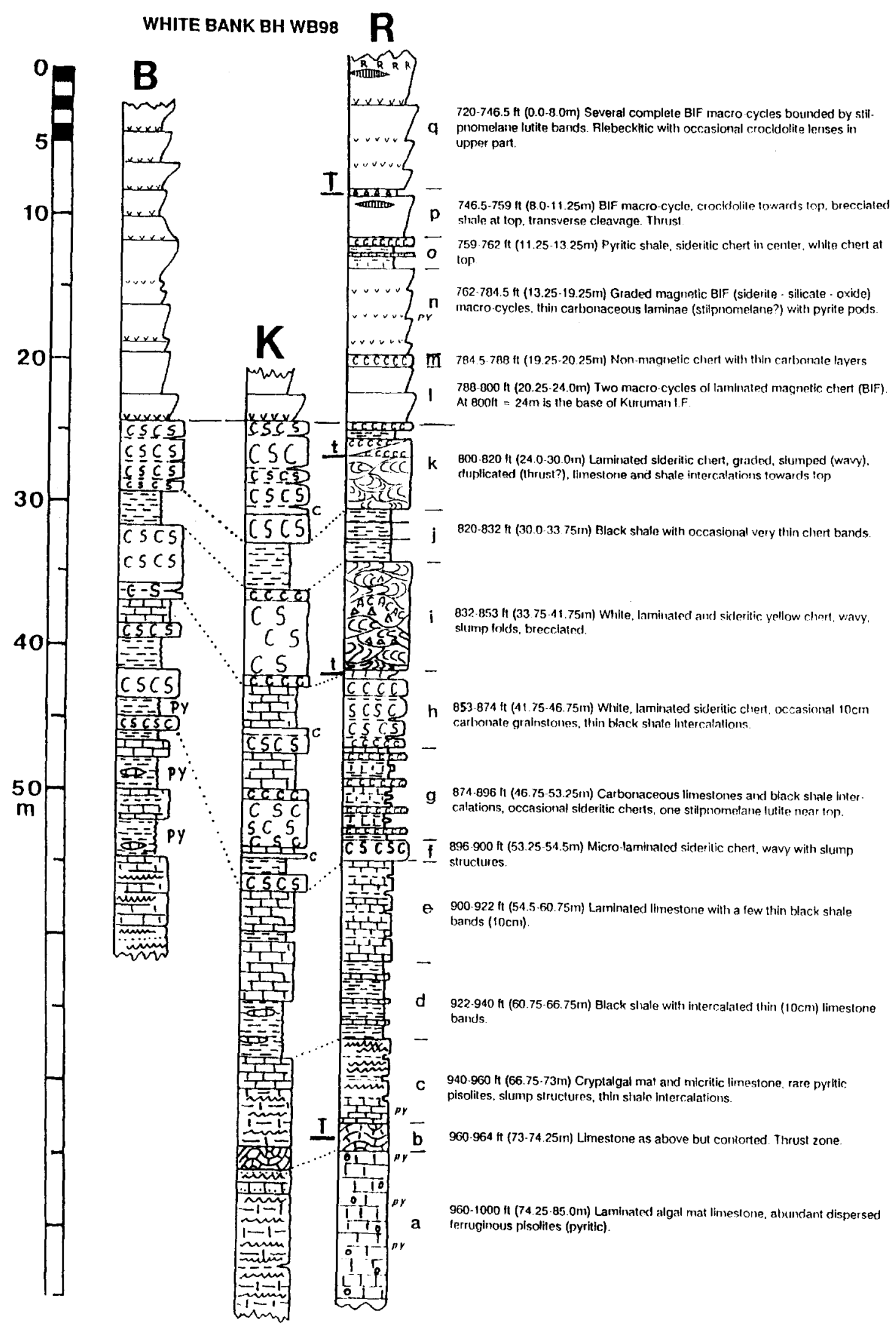

Fig. 9a. White Bank Bh wB-98. Stratigraphic Sections: Detall of transition zone. A borehole drilled on White Bank Mine a few figure. Klein and Beukes (1990) 1). A detailed log of this hole was published by Beukes in 1980 and is represented by "B" on this figure. Klein and Beukes (1990) published a somewhat different log (see K). We resurveyed the hole to be able to make compapossible but conspicuous, inexplicable profile that is only a few $\mathrm{km}$ from it. Correlations between the three logs (K, $R$ and $B)$ are $R$ Depths are given in feet below collar of description of the record. 

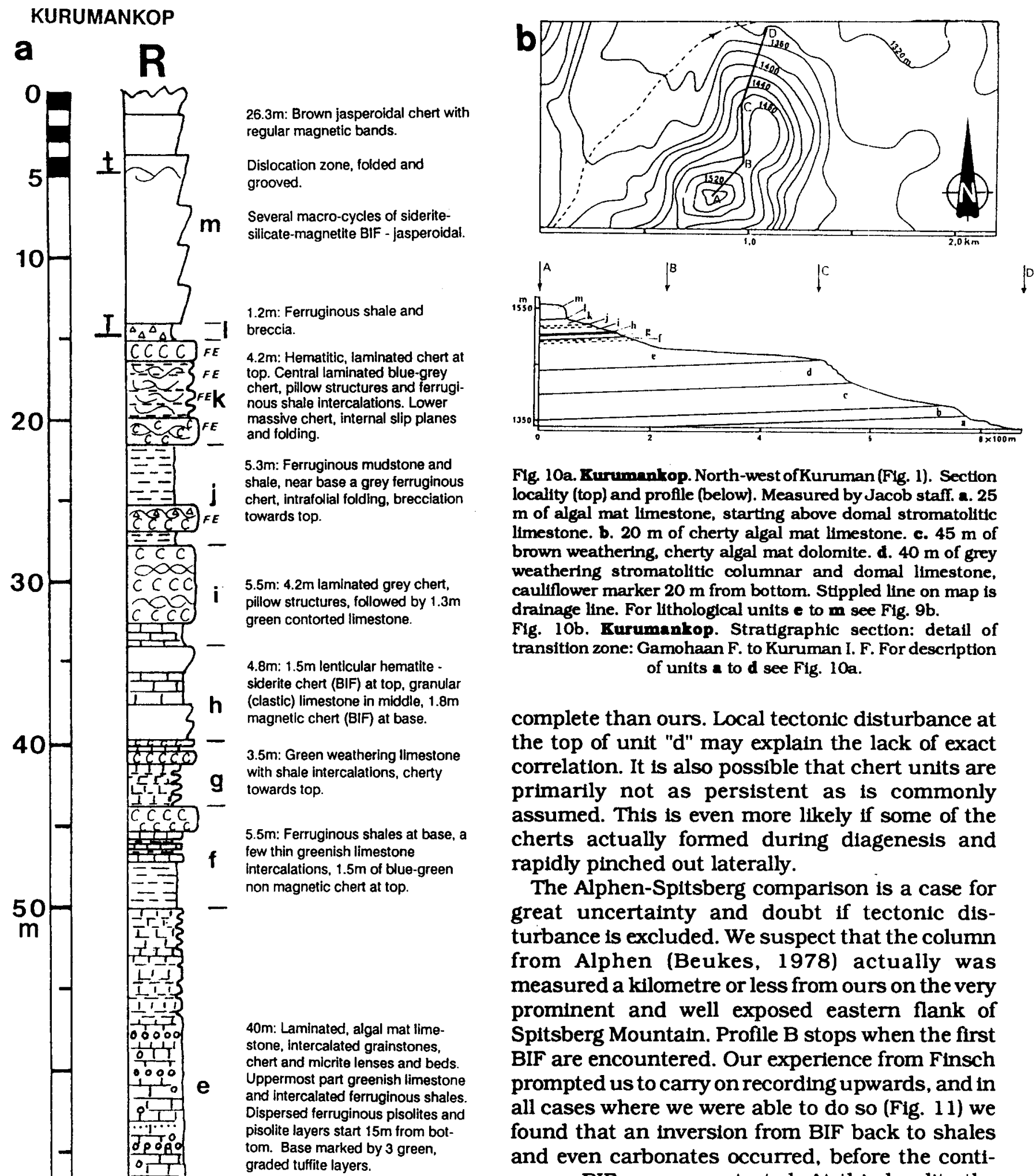

Fig. 10a. Kurumankop. North-west of Kuruman (Fig. 1). Section locality (top) and profile (below). Measured by Jacob staff. a. 25 $\mathrm{m}$ of algal mat limestone, starting above domal stromatolitic limestone. b. $20 \mathrm{~m}$ of cherty algal mat limestone. c. $45 \mathrm{~m}$ of brown weathering, cherty algal mat dolomite. d. $40 \mathrm{~m}$ of grey weathering stromatolitic columnar and domal limestone. cauliflower marker $20 \mathrm{~m}$ from bottom. Stippled line on map is drainage line. For lithological units e to $m$ see Fig. $9 \mathrm{~b}$.

Fig. 10b. Kurumankop. Stratigraphic section: detall of transition zone: Gamohaan F. to Kuruman I. F. For description of units a to d see Fig. 10a.

complete than ours. Local tectonic disturbance at the top of unit " $\mathrm{d}$ " may explain the lack of exact correlation. It is also possible that chert units are primarily not as persistent as is commonly assumed. This is even more likely if some of the cherts actually formed during diagenesis and rapidly pinched out laterally.

The Alphen-Spitsberg comparison is a case for great uncertainty and doubt if tectonic disturbance is excluded. We suspect that the column from Alphen (Beukes, 1978) actually was measured a kilometre or less from ours on the very prominent and well exposed eastern flank of Spitsberg Mountain. Profile B stops when the first BIF are encountered. Our experience from Finsch prompted us to carry on recording upwards, and in all cases where we were able to do so (Fig. 11) we found that an inversion from BIF back to shales and even carbonates occurred, before the continuous BIF-sequence started. At this locality the suggested correlation remains problematic because the two columns differ so much above as well as below the first chert units. As suggested here BIF in unit " $\mathrm{d}$ " may be the same as the one on the "baseline" for B (Alphen). Note also that three BIF zones and a tectonic disturbance occur in our profle. Thrusts in these rocks would be expected to form as scarcely visible narrow phyllonite zones preferably within shales or along the contacts of shale 
horizons with other beds. If on the other hand the two profiles should correlate laterally as they stand because of some chert and shale coincidences, it is clear that duplication of BIF has occurred in our column, which then almost certainly has a tectonic cause. Incidentally, we do not maintain that we were able to record all thrust horizons. Where the same core was logged twice by one author and by a second team, years after the first recordings, as for White Bank BH WB-98, appreciable differences were found that cannot be related entirely to varying interpretation of the same lithology (Figs 9 and 11). The core length between " $f$ " and " $k$ " in our section and in record $K$ apparently gained in length relative to $B$, published by Beukes (1980). This is unacceptable. We suspect that core lengths and core boxes could have been exchanged at some stage. If so this artifact introduces a high interauthor error and the example stresses the high priority that should be given to any permanent outcrop for profile studies.

For the Kurumankop sections we conclude that profile $B$ only records up to the first BIF, i.e., unit " $h$ " in profile R, because the two logs were certainly secured less than a hundred metres from each other near the top of the mountain (Fig. 10a). The comparison is fair to good considering that from units " $e$ " and " $f$ " upwards outcrops have to be searched for amongst coarse talus.

We have seen that some of the earlier recorded sections are apparently incomplete at least for the purpose we pursue here. It is also clear that factors such as inter-author errors, measuring slightly different sections, true lateral changes in lithology as well as localized synsedimentary and tectonic disturbances contribute to the uncertainty in trying to correlate thin units for long distances in these rocks.

Common to all profiles such as Hopefield, Gladstone, Gakarosa. Spitsberg and Kurumankop which, apart from local tectonic disturbances. appear to be complete and comparable to the Finsch Mine section, a 35-40 metres transition zone intervenes between underlying continuous carbonates and/or shales and on overlying continuous BIF-sequence. However, the upper parts of the columns below this transition zone are far from closely similar. For example the shaly facies vary much in thickness. Also what looks like the equivalent of this transition zone in the Derby and White Bank profiles obviously lacks a lower, well developed rhythmic BIF sub-zone. If this is correct and represents a primary feature, it shows that over distances of 10-20 km even well developed lithological zones consisting of several full macrocycles of BIF, are not laterally continuous. Apparently they develop into less distinct sideritic or hematitic chert-carbonate-sequences and subzones (compare Derby with Gladstone and Gakarosa) next door (Fig. 11).

Uncertainty in correlating sub-zones increases as one proceeds north of Spitsberg towards

Fig. 11. Correlation Diagram. Columns marked N (New) and R (Repeated) were recorded by the authors. Columns marked $\mathrm{B}$ are from Beukes $(1980 \mathrm{a}+\mathrm{b})$. Those marked $\mathrm{K}$ are from Beukes et al., 1990.

Legend: TSI = Tsineng Member; $\mathrm{KL}=$ Kliphuis Member; $\mathrm{MTL}=$ Matlipani Member; STFB = Stofbakkies Member. These names and the numbered zones are as introduced by Beukes $(1980 \mathrm{a}+\mathrm{b})$.

1) Complete (siderite-Fe-silicate-magnetite-hematite) BIF cycles not individually measured.

2) Complete individually measured macrocycles, commonly starting with stilpnomelane lutite (tuffite) followed by sideriteFe-silicate-magnetite-hematite band rhythmite.

3) As 2) but riebeckitic towards top with occasional thin lenses and bands of crocidolite.

4) Macro-breccia of BIF as in 2) resting on thin non-magnetic black cherts intercalated with thin ferruginous shales and cryptalgal and arenitic limestone.

5) Top: Mudstone-chert mesocycles. Bottom: Limestone-chert mesocycles.

6) Laminated, occasionally graded chert, $\mathrm{CC}=$ grey-blue to white chert; $\mathrm{FeC}=$ limonitic chert; $\mathrm{CH}=$ hematitic chert.

7) Like 6) but: $\mathrm{AC}=$ ankeritic; $\mathrm{CS}=$ sideritic

8) Like 6) but: excessively slumped and/or folded; occasionally brecciated; highly ferruginous laminae = FE.

9) Like 6) with iron-silicate bands in lower part and repetition of sequence by oblique slip (upper part).

10) Top = breccia of tectonic derivation. Bottom = mesobands of black or green volcanoclastics.

11) Recrystallized limestone and/or chert = jaspilite.

12) Lenses of chert and shale mainly in cartonate matrix.

13) Various shales and mudstones (clay stones), greenish-grey in lower parts of sections, black and commonly pyritic in upper parts of sections.

14) Dispersed ferruginous pisolites-originally pyritic.

15) Single layers of ferruginous pisolites-originally pyritic.

16) Shales with $S_{2}$ cleavage cutting across bedding fissility.

17) Cryptalgal mat limestone.

18) Carbonaceous cherts.

19) Various laminated algal mat limestones and intramic sparites; dolomite in lower part; if ferruginous = Fe.

20) Algal grainstones.

21) Contorted, ferruginous shale.

22) Domal stromatolite.

23) Fenestral structures and columnar structures in carbonates.

24) Lenses of cryptalgal limestone.

25) Algal mat limestone with dispersed ferruginous pisolites-intensely contorted. 


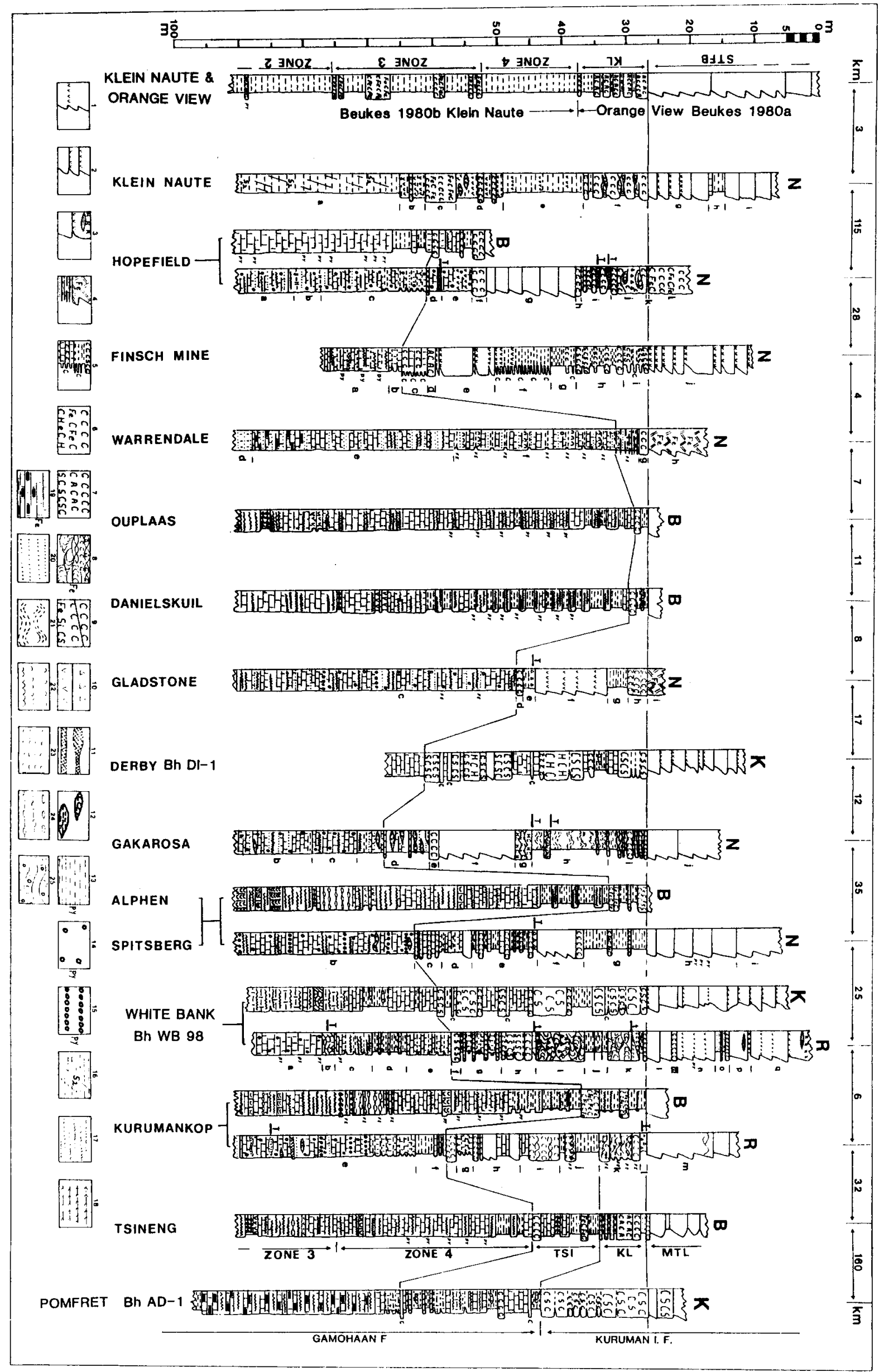


Tsineng and Pomfret (Fig. 11). This is obvious when what has been named the Tsineng Member by Beukes $(1980 \mathrm{a}+\mathrm{b})$ and Beukes et al. (1990) is followed out as demarcated by the tentative correlation line in Fig. 11. Any lithology from full BIFcycles to black shales, white cherts and carbonates occurs in this unit. When trying to follow out the Kliphuis Member as mainly ankeritic cherts southwards from Tsineng it is clear that Kurumankop B, Alphen, Danielskuil, Ouplaas and Warrendale are either incomplete sections or the Kliphuis Member is very discontinuous. At Gakarosa an apparently "complete" section except for some tectonic disturbance, has developed no Kliphuis Member.

At Finsch it is either atypical or absent too. At Pomfret, Hopefield and Klein Naute, its character and thickness have changed considerably. However, Finsch and several of the other "complete" sections also have an ankeritic thicker chert below the lowermost BIF-sequence, that occasionally somewhat resembles the Kliphuis Member.

The tentattve correlation line in Fig. 11 arbitrarlly connects the lowermost chert band found in the upper part of the Gamohaan Formation in all profiles. Considering the difficulties mentioned above in correlating beds and sub-zones laterally in this transition zone, the implication is not that this line connects the same band or bed.

However, it is true that a transition zone exists, consisting of various vertical and lateral combinations of cherts, carbonates, shales, BIF and tuffites, all of which are most certainly lenticular and may laterally even grade into each other. We feel that factors related to the environment of deposition play a primary role in this diversity and secondary effects certainly complicated matters.

If the above conclusion is acceptable then the environment at that time was characterized by local instability everywhere. The change-over from carbonate to BIF precipitation was marked by setbacks and new advances, repeating many times and alternating from place to place. The only stratigraphic element that is common to the entire $450 \mathrm{~km} \mathrm{~N}$-S extent of these rocks is its variability. It seems as if both meso- and macro-environmental realms were constantly competing, trying to replace or eliminated each other in time and place as one chemical environment evolved through many oscillations into a new one.

If the beginning of transition-instability is marked by the first chert band or zone in each section (without implying that they are the same band) it is clear that from south to north a gradual change in the predominant lithology and therefore probably the environmental character takes place. This is revealed in the thick shale loverlying the Campbell carbonates) only interrupted by a few ferruginous cherts in the south, by the well developed lower BIF-zone in the central area making up about $1 / 4$ to $1 / 3$ of the transition zone and by carbonates becoming increasingly dominant right up to the thick sideritic cherts below the BIF at Pomfret. There is no doubt that in general (but again with many localized variations to the theme) the transition was influenced by more prominent clastic input intervening between carbonate and BIF precipitation in the south. Beukes (1978, 1980 $a+b, 1983$ ) and Beukes et al. (1990) have interpreted this scenario as proof of marine conditions throughout and a sea transgressing from $\mathrm{S}$ to $\mathrm{N}$ across a carbonate platform with a southwarddeepening waterbody.

\section{ENVIRONMENTAL IMPLICATIONS}

We have suggested a shallow, mixed-water depositional environment for the Finsch profile. It seems as if the stratigraphically so diverse transition zone fully supports this argument as against a southward deepening marine basin.

From Hopefield to Kurumankop (Fig. 11) environmental conditions very similar to those at Finsch seem to have prevailed above the central part of the study area, the carbonate platform of Beukes (1978-1980 a + b). They are marked by repeated attempts at BIF-precipitation here and there, alternating with a re-establishment of carbonate facies and an irregular intermittent distribution of fine, clastic material. We see this as typical of a fluctuating, unstable shallow water environment with varying river influx from a topographically very subdued hinterland. The initially marine depositional basin was emerging very slowly. The chemistry of the clastics from the transition zone is what one would expect from the erosion of a deeply weathered regolith that formed in a humid. warm climate largely from an emerging carbonate platform. These sediments were redistributed by many small, local and sluggish streams into the waning basin. This basin could have been sheltered from the sea at times and the situation (if at all comparable with Mesozoic plate tectonic settings) is more reminiscent of a trailing edge or "passive" margin, than it is of a foreland basin. This is also borne out by the regional stratigraphy lacking a comparison with foreland basin features as discussed by Hoffman (1987). The changing volcanic input to the basin that began with proximal mafic tuffs in the Campbell Group (Altermann, 1991) and proceeded into the Griquatown Group with a distal andesitic and trachy-andesitic tuffite suite (Lamprecht, 1993), points more toward a falled attempt at cratonic separation. This is not the place to argue that at least some of the chemical evidence produced by Bcukes et al. (1990) may 
also be interpreted as supporting a shallowing as against a deepening basin. We only refer to our brief treatment of some chemically derived arguments based on analyses from Finsch, which seem to fit a shallowing, mixed (or brackish) water environment. Sheltering, sluggish river transport and an oxygen deficient atmosphere with dominant bacteria and prokaryotic algae of course are a prerequisite. A constantly repeated imbalance between rate of precipitation, sheltering, epeirogenesis and eustasy, controlled the $\mathrm{pH}$. $\mathrm{Eh}$, water depth, salinity and microbiology of this water body. The ensuing iron formations with a tectonic thickness of several hundred metres (Altermann + Hälbich, 1990) were laid down under stabilized chemical conditions, following at first a rigorously controlled biochemical rhythm resulting in vertically superposed BIF-cycles on various scales (Kuruman Iron Formation). Very low lying, modern platforms of similar size and amongst others with cyclic chemical sediments are known from the Ram of Kutch, south of Karachl, along India's north-western passive margin (Glennie, 1970) where annual wind-driven tides play a major role in the sedimentation history of an unsheltered depository.

A continuity of beds indicative of a deepening water-body does not exist in the transition zone and has not been demonstrated for the Kuruman Iron Formation by detailed stratigraphic follow-up in the field. This would have to carefully eliminate the effect of various post-sedimentary compressional tectonic episodes followed by tensional ones and intrusive events.
The upper BIF, the Griquatown Iron Formation, has long been known (e.g., Beukes, 1978: 1980 a + b) for its many shallow water indicators such as erosion, redeposition and desiccation features. We have recently discovered signs of evaporation and at least temporary elevation of soft sediments above groundwater table in this formation and in the Kuruman Iron Formation (Fig. 12). Barley etal. (1979) recorded Archean gypsum rosettes in cherty sediments from N. W. Australia which are similar to our Fig. 12.

It seems that an intertidal to supratidal shallow marine to mixed water situation can be shown to apply for at least the upper Campbell Group carbonates (Altermann and Herbig, (1991) in the south of the study area, the transition zone and the largely redeposited Griquatown BIF (Table 2). Only the Kuruman Iron Formation seems to have been deposited under rigidly controlled chemical conditions, perhaps under the influence of seasonal factors. A steadily shallowing basin with final reworking of chemically laid down BIF points to overall regression rather than transgression, with some steadying of vertical tectonics during the deposition of the Kuruman BIF.

\section{STRATIGRAPHIC CLASSIFICATION}

We propose that the stratigraphic subdivision of a transition (the upper Gamohaan Formation of Beukes, $1980 \mathrm{a}+\mathrm{b}$ ) into members is abandoned in favour of a transition zone, some 32 to 40 metres thick where fully developed. It starts with the first

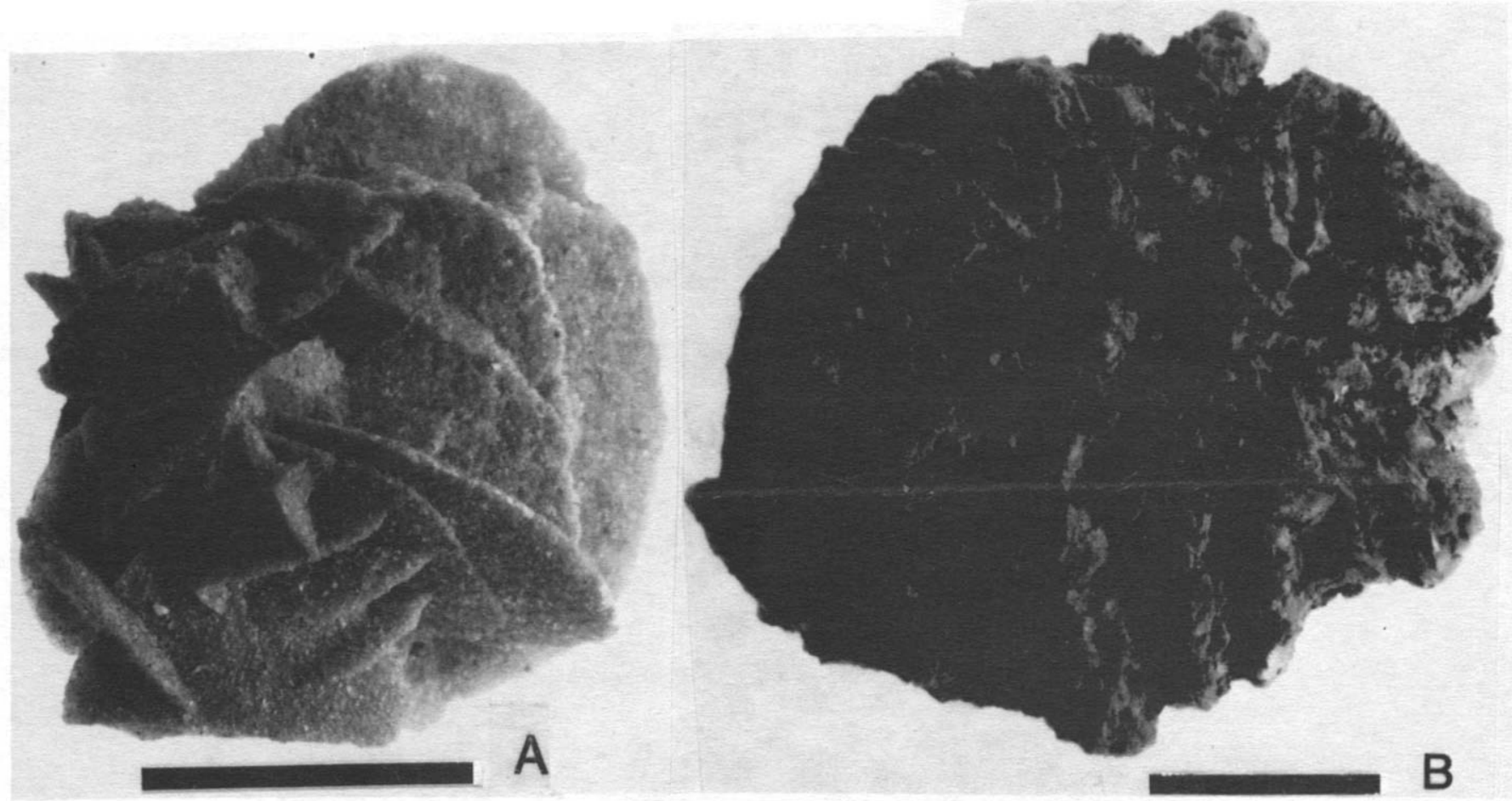

Fig. 12A. Gypsum rose of recent age. Scale bar $=2 \mathrm{~cm}$. the lower Beaufort Group (about $230 \mathrm{Ma}=$ Upper Permian). Scale bar $=2 \mathrm{~cm}$.

B. Diagenetically misformed and chertified gypsum roses from 

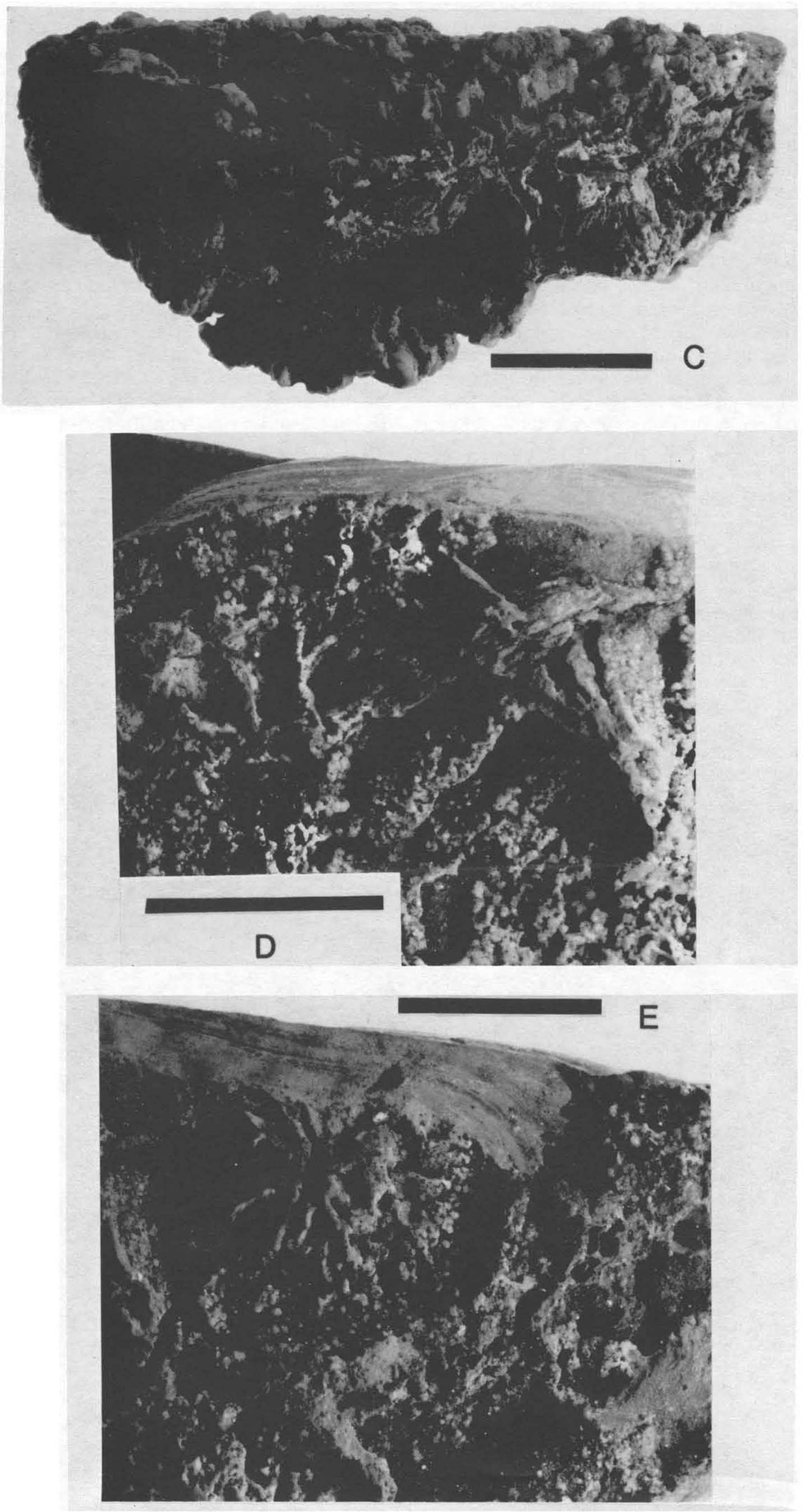

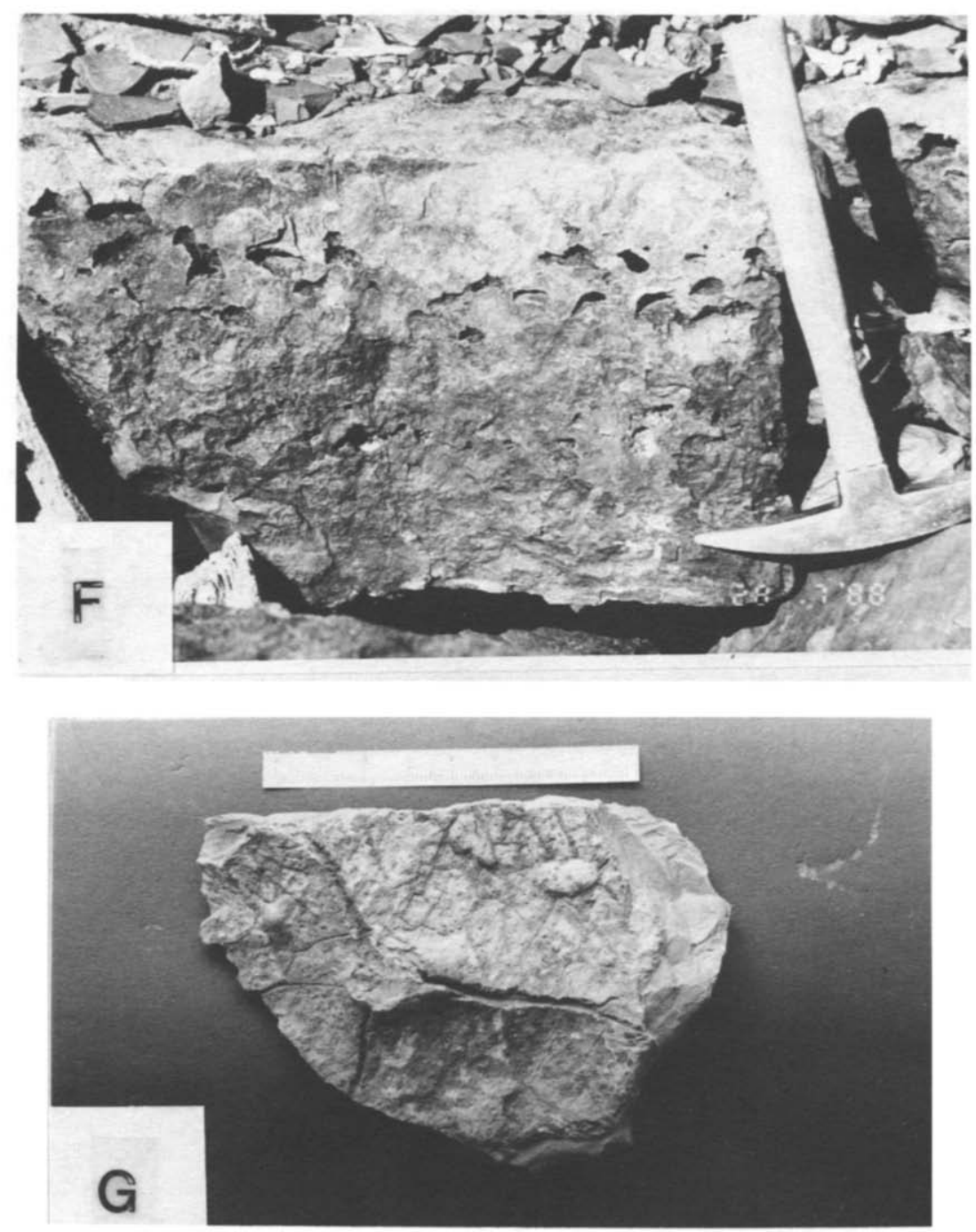

Fig. 12C. Diagenetically misformed and chertified gypsum roses from the lower Beaufort Group (about 230 Ma = Upper Permian). Scale bar $=2 \mathrm{~cm}$. $\quad \mathrm{D}=\mathrm{E}$. Chertified gypsum roses of the Griquatown Iron Formation from Tasmania farm, some $30 \mathrm{~km}$ south of Griquatown. Age $2500 \mathrm{Ma}$. Secondary, nodular chertification has destroyed some of the finer detail. The disturbed horizon in which the structures occur was obviously a more porous, erosion based unit-apparently a clay pellet conglomerate. Scale bar = $2 \mathrm{~cm}$. F. Tsineng Member, Kuruman Formation, ca. 50 m above the Naute Shales on Klein Naute. Large, fenestrae-like structures occur in what appears to be granular, sideritic chert. In this horizon silicified gypsum rosettes similar to those in the Griquatown IF (D + E) were found. (G) Just a few decimetres above (F). Polygonal cracks, resembling mudcracks have developed on a bedding plane. Scale bar $=8 \mathrm{~cm}$.

chert and ends at the base of the continuous BIFsequence. The most drastic chemical change, and by implication a change in environmental conditions, also takes place at or just above the base of the transition (see Finsch profile discussion above and Table 1). Beukes et al. (1990) have found very similar chemical changes starting just above the lowest cherts in their Pomfret, Derby and White Bank profiles. Most characteristic is the sudden increase in $\mathrm{Fe}$-deposition, which equals or exceeds the $15 \%$ minimum required for iron-stones.

Were it not for the high lithological variability, the base of the transition zone could be seen as the beginning of the Kuruman Iron Formation. There are two options for a better classification:

a) The transition zone is named the Finsch
Member of the Kuruman Iron Formation because it is part of that formation on grounds of bulk $\mathrm{Fe}$ content, and it is best exposed and well studied in the Finsch opencast mine (Lamprecht, 1993). The major unifying factor is its diversity of lithology as compared to the underlying carbonates and/or shales and the overlying BIF.

b) Because it is mappable on a 1: 50000 scale, it has developed regionally and can also be delineated readily on all known complete crosssections, its rank could even be elevated to that of the Finsch Transition Formation. The type locality for the stratotype would be the Finsch opencast. Reference stratotypes would be on Klein Naute. Kurumankop and at Pomfret Bh AD-1.

We feel that Formation status for the transition 
zone is necessary to "portray the rock framework satisfactorily and work out the geological history" (SACS, 1980, p. 648) of the Griqualand West Sequence.

Acknowledgements - We thank the following institutions and people: The C. S. I. R. for financial support through the F. R. D. and the National Geoscience Programme. D. J. Oosthuyzen from Koegasbrug for his kind hospitality and support in many ways. Several farmers along the Asbestos-Kuruman Hills for permission to visit and study outcrops on their farms. Griqualand Exploration and Finance Company for allowing us to investigate their borehole core and secure samples and for permission to make use of their facilities at Koegasbrug. The manager at Finsch Diamond Mine (De Beers Pty. Ltd) gave permission to work on the benches of the open pit, provided logistic support and subsidized the stay of $D$. Lamprecht at the mine for several months. P. Lawless, resident geologist at Finsch Mine for his professional assistance and very illuminating discussions. J. P. Ie Roux for reading an early version of the manuscript and suggesting valuable improvements. S. Smit for her patience and meticulous typing. N. J. Beukes for arranging several $\mathrm{d} \mathrm{S}^{34}$ analyses to be conducted. Our colleagues at Stellenbosch and $N$. J. Beukes for fruitful discussions. D. D. Klemm, G.C. Amstutz and I. Plimer for crytically reading the final manuscript and suggest-ing several improvements.

\section{REFERENCES}

Altermann, W. 1991. Sedimentary and geochemical characteristics of tuff layers of the Lower Proterozoic Campbellrand Carbonates in Griqualand West. Conference on Precambrian. Sedimentary basins of southern Africa. Univ. Pretoria.

Altermann, W. and Halbich, I. W. 1990. Thrusting, folding and stratigraphy of the Ghaap Group along the southwestern margin of the Kaapvaal Craton. S. Afr. J. Geol. 93, 556-616.

Altermann, W. and Halbich, I. W. 1991. Structural history of the southwestern comer of the Kaapvaal Craton and the adjacent Namaqua realm: New observations and a reappraisal. Precambrian Res. 52. 133-166.

Altermann, W. and Herbig, H-G. 1992. Tidal flat deposits of the lower Proterozoic Campbell Group along the southwestern margin of the Kaapvaal Craton. northern Cape Province, South Africa. J. Afr. Earth. Sci $13,3$.

Barley, M. E., Dunlop, J.S. R., Glover, J. E. and Groves, D. I. 1979. Sedimentary evidence for an Archean shallow-water volcanic-sedimentary facies, Eastern Pilbara Block. Western Australia. Earth and Planet. Scl. Letters 43, 74-84.

Baur, M. E., Hayes, J. M., Studley, S. A. and Walter, M. R. 1985. Millimeter-scale variation of stable isotope abundances in carbonates from banded iron formations in the Hamersley Group of Western Australia. Econ. Geol 80, 270-282.
Beukes, N. J. 1978. Die karbonaatgesteentes en ysterformasies van die Ghaap-Groep van die transvaal Supergroep in Noord Kaapland. Unpublished $P h . D$. thesis, Rand Afrikaans University, Johannesburg, 500 p.

Beukes, N. 1980a. Stratigrafie en litofasies van die Campbellrand-Subgroep van die Proterofitiese GhaapGroep, Noord Kaapland. Trans. Geol. Soc. S. Afr. 83,141170.

Beukes, N. J. 1980b. Lithofacies and stratigraphy of the Kuruman and Griquatown Iron Formations, Northern Cape Province, South Africa. Trans. Geol. Soc. S. Afr. 83, 69-86.

Beukes, N. J. 1983. Paleoenvironmental setting of iron formations in the depositional basin of the Transvaal Supergroup, South Africa. In: Trendall, A. F. and Morris, R. C. (Editors), Iron Formation: facts and problems. Developments in Precambrian geology 6, Elsevier, 131-210.

Beukes, N. J., Klein, C., Kaufman, A. J. and Hayes, J. M. 1990. Carbonate petrography, kerogen distribution, and carbon and oxygen, isotope variations in an Early Proterozoic transition from limestone to iron-formation deposition. Transvaal Supergroup, South Africa. Econ. Geol 85, 4, 665-690.

Glennie, K. W. 1970. Desert sedimentary environments. Developments in sedimentology 14, Elsevier.

Hoefs, J. 1987. Stable isotope geochemistry. 3rd edition. Springer Verlag, Berlin.

Hoffman, P. F. 1987. Early Proterozolc foredeeps, foredeep magmatism, and Superior-type iron formation of the Canadian shield. In: Proterozoic lithospheric evolution. (Edited by Kröner, A), Geodynamics Series 17. American Geophysical Union, 85-98.

Horstmann, U. E. and Hälbich, I. W. submitted. Mesoband geochemistry of banded iron formation of the Griqualand West Sequence, Northern Cape Province, South Africa in comparison with other Precambrian iron formations, Chemical Geology.

La Berge, G. L. 1966a. Altered pyroclastic rocks in ironformation in the Hamersley Range, Western Australia, Econ. Geol. 61, 147-161.

La Berge, G. L. 1966b. Altered pyroclastic rocks in South African iron formation. Econ. Geol. 61, 572-581.

Lamprecht, D. 1992. A vertical transition from carbonates to iron formation in the Griqualand West Sequence from Finsch Mine. M. Sc thesis, University of Stellenbosch, unpublished.

Schidlowski, M., Hayes, J. M. and Kaplan, I. R. 1983. Isotopic inferences of ancient biochemistries: carbon, sulfur, hydrogen and nitrogen. In: Earth's earliest biosphere: Its origin and evolution (Edited by Schopf, I. W.), Princeton University Press, 149-186.

South African Committee for Stratigraphic (SACS), 1980. Stratigraphy of South Africa. Part 1. (Comp. L. E. Kent). Lithostratigraphy of the Repuhlic of South Africa, South West Africca/Namibia, and the Republics of Bophuthatswana, Transkei and Venda: Handb. Geol. Surv. of S. Afr. 8.

Wedepohl, K. H. Editor 1970. Handbook of Geochemistry, II/1, Sodium. 